The Cryosphere Discuss., 5, 811-854, 2011

www.the-cryosphere-discuss.net/5/811/2011/

doi:10.5194/tcd-5-811-2011

(c) Author(s) 2011. CC Attribution 3.0 License.

\title{
Modelling the temperature evolution of permafrost and seasonal frost in southern Norway during the 20th and 21st century
}

T. Hipp, B. Etzelmüller, H. Farbrot, and T. V. Schuler

Department of Geosciences, University of Oslo, Oslo, Norway

Received: 2 March 2011 - Accepted: 3 March 2011 - Published: 11 March 2011

Correspondence to: T. Hipp (tobias.hipp@geo.uio.no)

Published by Copernicus Publications on behalf of the European Geosciences Union.

$5,811-854,2011$

Temperature evolution modelling of permafrost and seasonal frost

T. Hipp et al.

\section{Title Page}

Abstract Introduction

Conclusions References

Tables Figures

14

4

Back

Close

Full Screen / Esc

Printer-friendly Version

Interactive Discussion 


\section{Abstract}

A heat flow model was used to simulate both past and future ground temperatures of mountain permafrost in Southern Norway. A reconstructed air temperature series back to 1860 was used to evaluate the permafrost evolution since the end of the Little

5 Ice Age in the region. The impact of a changing climate on discontinuous mountain permafrost until 2100 is predicted by using downscaled temperatures from an ensemble of downscaled climate models for the A1B scenario. From 13 borehole locations two consecutive years of ground temperature, air temperature and snow cover data are available for model calibration and validation. The boreholes are located at different elevations and in substrates having different thermal properties. With an increase of air temperature of $\sim+1.5^{\circ} \mathrm{C}$ over $1860-2010$ and an additional warming of $+2.8^{\circ} \mathrm{C}$ towards 2100 in air temperature, we simulate the evolution of ground temperatures for the borehole locations. According to model results, the active-layer thickness has increased since 1860 by about $0.5-5 \mathrm{~m}$ and $>10 \mathrm{~m}$ for the sites Juvvass and Tron, re15 spectively. The simulations also suggest that at an elevation of about $1900 \mathrm{~m}$ a.s.l. permafrost will degrade until the end of this century with a likelihood of $55-75 \%$ given the chosen A1B scenario.

\section{Background and objectives}

Permafrost is defined as ground that stays at or below $0^{\circ} \mathrm{C}$ for more than two consecutive years (French, 1996). Permafrost in general and mountain permafrost in particular have faced an increasing interest due to its sensitivity to climate variation and importance for geomorphologic and geotechnical processes (Harris et al., 2009), such as slope stability and natural hazards (Gude and Barsch, 2005; Huggel et al., 2010; Gruber et al., 2004a; Fischer et al., 2006; Haeberli, 1992). Permafrost is a governing 25 factor in this respect, and understanding of ground thermal regimes is of importance for understanding surface and sub-surface processes in mountain environments. Thus,

\section{Temperature evolution modelling of permafrost and seasonal frost}

T. Hipp et al.

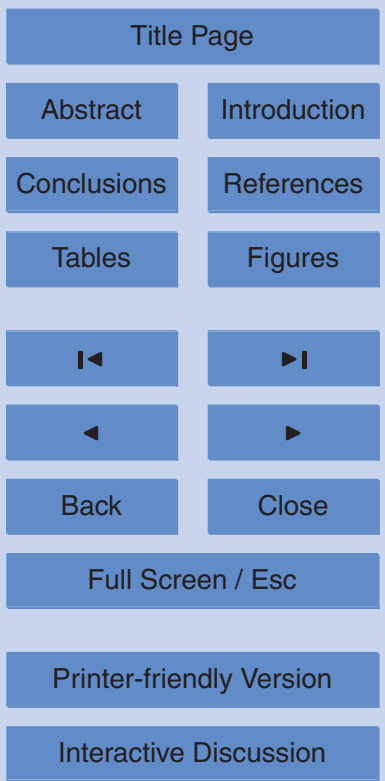


there is a need of addressing the response of ground temperatures (GT) to climate forcing, especially the modulation of the response of GTs to the effect of snow cover and different types of surficial material and bedrock.

In Scandinavia and especially in northern Norway, Iceland and Svalbard, multiple 5 shallow boreholes have been drilled to continuously monitor ground thermal regimes and the relation between atmosphere and ground in terms of energy exchange since 1999 (Etzelmüller et al., 2007; Farbrot et al., 2007; Christiansen et al., 2010; Isaksen et al., 2003; Isaksen et al., 2000). In summer 2008 a monitoring network for mountain permafrost in Southern Norway was installed including boreholes to a depth of $1030 \mathrm{~m}$, air and ground temperature loggers, a fully equipped weather station and snow measurement set ups. The network addresses environmental gradients in southern Norway related to elevation and continentality (Farbrot et al., 2011), and provides the basis for calibrating and validating transient heat flow models.

One-dimensional heat flux models have been applied successfully in various stud15 ies related to permafrost occurrence, distribution and to model the response of arctic permafrost to a changing climate, such as in Canada (Zhang et al., 2003; Zhang et al., 2006, 2008; Burn and Zhang, 2009), the Russian arctic (Malevsky-Malevich et al., 2001; Romanovsky et al., 2007; Sazonova et al., 2004), Svalbard (Etzelmüller et al., 2011) and Alaska (Biesinger et al., 2007; Osterkamp and Romanovsky, 1999). But also in more complex mountain regions as the European Alps transient modelling studies of permafrost occurrence and distribution on local and regional scales have been undertaken (Gruber et al., 2004b; Hoelzle et al., 2001; Noetzli and Gruber, 2009; Noetzli et al., 2007; Stocker-Mittaz et al., 2002; Luetschg et al., 2008). Such models can be driven by air or ground surface temperature (GST) series, either historical or derived from global climate models. For Scandinavia in general, and southern Norway in particular, instrumental data show a warming since the end of the Little Ice Age (LIA) and an increased warming trend since the 1990s (Serreze et al., 2000). Global climate models predict an accelerating warming until the end of this century (Benestad, 2005), which potentially would lead to major changes in the ground thermal regime in Scandinavian

\section{Temperature evolution modelling of permafrost and seasonal frost}

T. Hipp et al.

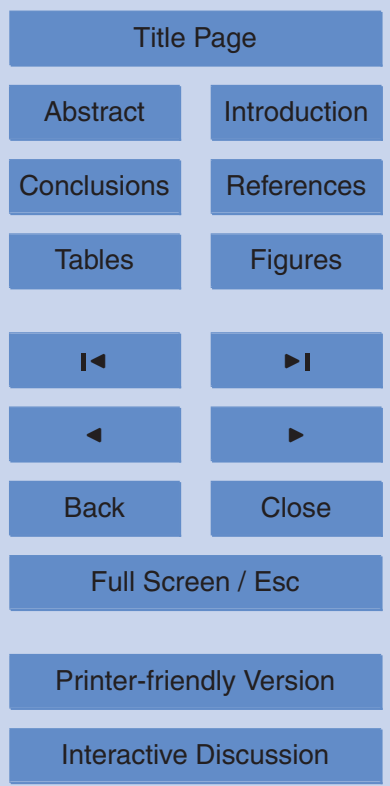


mountains.

The objective of this study is to analyze the ground thermal response to historical and future air temperature $\left(T_{\text {AIR }}\right)$ variation in different environmental settings in terms of elevation, vegetation, snow and sediment cover. This improved understanding is

5 a crucial basis for spatially distributed permafrost modelling, and for understanding geomorphological process patterns and landscape development (Etzelmüller et al., 2003).

To reach this aim, we used a simple 1D heat flow model recently applied for Svalbard and Iceland (Etzelmüller et al., 2011; Farbrot et al., 2007), and applied it for together 13 10 borehole locations in southern Norway. The model was calibrated and validated using measured borehole data and subsequently forced by historical $T_{\text {AIR }}$ series reaching back to 1860 , and climate change scenarios (A1B) down-scaled to certain climate stations (Benestad 2010), projecting the evolution of $T_{\text {AIR }}$ until 2100.

\section{Setting and climate at the study sites}

15 The borehole measurements used in this study come from over three major sites (Fig. 1): Juvvasshøe $\left(61^{\circ} 40^{\prime} \mathrm{N}, 08^{\circ} 22^{\prime} \mathrm{E}, 1894 \mathrm{~m}\right.$ a.s.I.), Jetta $\left(61^{\circ} 53^{\prime} \mathrm{N}, 9^{\circ} 17^{\prime} \mathrm{E}\right.$, $1640 \mathrm{~m}$ a.s.I.) and the Tron massif $\left(62^{\circ} 10^{\prime} \mathrm{N} 10^{\circ} 41^{\prime} \mathrm{E}, 1560 \mathrm{~m}\right.$ a.s.I.). In addition to the PACE boreholes, a total number of 12 boreholes were drilled in August/September 2008 along altitudinal gradients at each site. Ground temperatures were recorded in

20 2-hour intervals over two consecutive years from August 2008 to August 2010. In addition the GST, $T_{\text {AIR }}$ and snow depth (SD) is recorded at most boreholes. From the PACE borehole long time series of GT, GST and $T_{\text {AIR }}$ from 1999 until 2010 are available. Low-cost $\left( \pm 0.5^{\circ} \mathrm{C}\right.$ accuracy $)$ iButton temperature loggers were installed at fixed heights along the pole carrying the air temperature sensor. These measurements are used to roughly determine the snow depth evolution during winter at the sites. At the uppermost borehole at Tron (Tro-BH1, $1640 \mathrm{~m}$ a.s.I.) a meteorological station was set up providing hourly data of air temperature, wind speed and direction, relative humidity,

\section{Temperature evolution modelling of permafrost and seasonal frost}

T. Hipp et al.

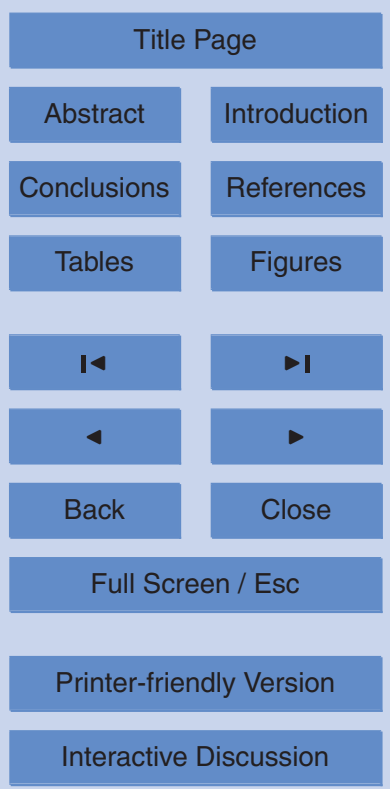


incoming and outgoing short and long wave radiation. A sonic sensor is continuously measuring the snow depth. A more detailed description of the sites and the instrumentation is given by Farbrot et al. (2011).

\subsection{The borehole sites}

5 Juvvasshøe (1884 $\mathrm{m}$ a.s.I.) is a high mountain site situated in the vicinity of the highest mountain of Norway, Galdhøpiggen (2469 m a.s.I.) (Fig. 1c). The site has a comparatively long history of permafrost research (Isaksen et al., 2003; Isaksen et al., 2001; Isaksen et al., 2002; Ødegård et al., 1996; Ødegård et al., 1999; Ødegård et al., 1988; Ødegård et al., 1992) with first ground temperature measurements started by Ødegård et al. (1992) and the later drilling of the $129 \mathrm{~m}$ deep PACE borehole (Harris et al., 2001; Isaksen et al., 2001). The surface of the site is characterized by extensive blockfields at higher elevations and finer till material at lower elevations (Ødegård et al., 1988). Six boreholes were drilled in addition to the existing PACE boreholes along an altitudinal transect ranging from $1884 \mathrm{~m}$ a.s.I. (PACE) down to $1307 \mathrm{~m}$ a.s.l. (Juv-BH6)

15 (Fig. 1c). The boreholes have different stratigraphies: PACE, Juv-BH1 and Juv-BH3 are located in block fields, Juv-BH4 was drilled in bedrock and Juv-BH6 in sand-rich ground moraine.

At Jetta (Fig. 1b) blockfields are present down to elevations of $1500 \mathrm{~m}$ and $1100 \mathrm{~m}$ a.s.l. on the north and south exposition, respectively, with thicknesses ranging from 3 to $10 \mathrm{~m}$ (Bø 1998). Three boreholes were drilled $10 \mathrm{~m}$ into bedrock at $1560 \mathrm{~m}$ a.s.l. (Jet-BH1), 1450 ma.s.l. (Jet-BH2) and $1218 \mathrm{~m}$ a.s.l. (Jet-BH3).

Tron (Fig. 1d) is located further east in a more continental climate setting. The uppermost of totally three boreholes (Tro-BH1, $1640 \mathrm{~m}$ ) was drilled $30 \mathrm{~m}$ into a block field, the other two were drilled $10 \mathrm{~m}$ into fine-grained morainic material.

\section{Temperature evolution modelling of permafrost and seasonal frost}

T. Hipp et al.

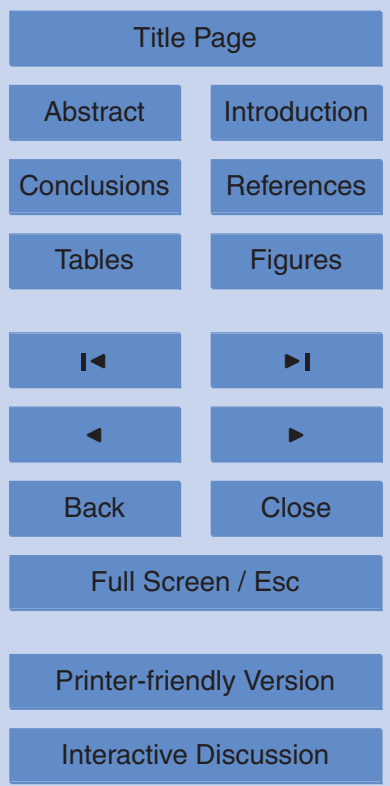




\subsection{Climate conditions at the study sites}

At each borehole continuous series of $T_{\text {AIR }}$, GST, GT and snow cover are recorded since 2008 (Fig. 4). At the PACE borehole these parameters are measured since 1999 (Isaksen et al., 2007; Isaksen et al., 2001).

$5 \quad$ At Juvvass mean annual air temperatures (MAAT) in 2009 range from $-3.2^{\circ} \mathrm{C}$ on Juvvasshøe (1861m a.s.l.) to $-0.5^{\circ} \mathrm{C}$ at $1307 \mathrm{~m}$ a.s.l. resulting in an average altitudinal lapse rate of $0.5^{\circ} \mathrm{C} 100 \mathrm{~m}^{-1}$ (Farbrot et al., 2011). At higher elevations snow cover is strongly variable, but generally thin due to strong wind redistribution. A thick snow cover, however, is found at lower elevations. Thus, Juv-BH1 does not show a continuous snow cover exceeding 10-20 cm, while the lower boreholes (Juv-BH5 and especially Juv-BH6) have a vegetated surface and a pronounced snow cover (Farbrot et al., 2011). At Tron MAAT in 2009 ranged from $-3.5^{\circ} \mathrm{C}$ to $+1.1^{\circ} \mathrm{C}$ and Tro-BH1 and Tro-BH2 show thick and long snow cover during both seasons.

The three borehole sites are situated along a continentality gradient from a more 15 maritime influenced climate at Juvvasshøe to a more continental climate setting at Tronfjell (Farbrot et al., 2011). Mean monthly air temperatures (MMAT) of the last climate normal 1961-1990 for all three sites and the mean deviation of 2008 and 2009 (until August only) to the normal are shown in Fig. 2. Due to the lower elevation, Jetta shows warmer summer and winter temperatures. However, although the site at Tron is about $250 \mathrm{~m}$ lower than Juvvasshøe, $T_{\text {AIR }}$ is similar or even colder than at Juvvasshøe (Fig. 2a). Using the altitudinal lapse rate derived from observations (Farbrot et al., 2011) $T_{\text {AIR }}$ at $1640 \mathrm{~m}$ a.s.l. is $-2.3,-2.2$ and $-3.8^{\circ} \mathrm{C}$ at Juvvasshøe, Jetta and Tron, respectively, demonstrating the increasing continentality towards Tron.

The two seasons devided into 1 September 2008-31 August 2009 (S1) and 1 25 September 2009-31 August 2010 (S2) were analyzed independently and used in the following to derive seasonal means and differences. Two substantial different seasonal patterns have been recorded (Fig. 2b). The MAAT during $\mathrm{S} 2$ was in average $+1.4^{\circ} \mathrm{C}$ and $+1.1^{\circ} \mathrm{C}$ colder at Juvvass/Jetta and Tron, respectively, than S1. The winter 2008-

$5,811-854,2011$

\section{Temperature evolution modelling \\ of permafrost and seasonal frost}

T. Hipp et al.

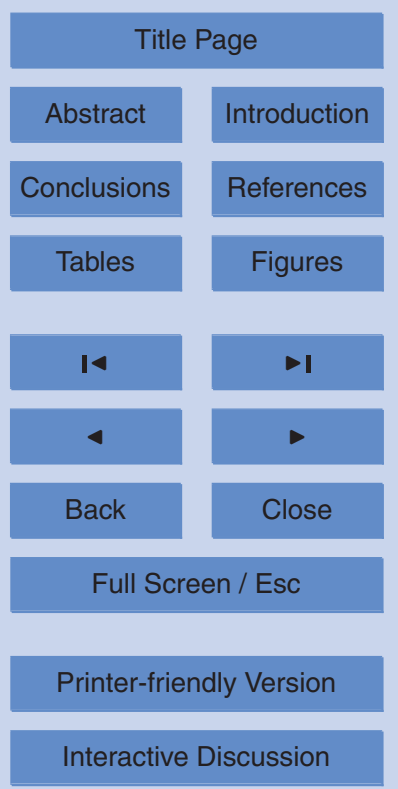


2009 did not show any strong deviation from the period 1961-1990, but positive deviations of up to $+5^{\circ} \mathrm{C}$ were recorded during spring and summer. The winter 2009/2010 was much colder than the normal period, with negative deviations of up to $-4.5^{\circ} \mathrm{C}$ in relation to the normal period (Fig. 2b). In average, deviations of $+0.7^{\circ} \mathrm{C}$ for $\mathrm{S} 1$ and $5+1.1{ }^{\circ} \mathrm{C}$ for $\mathrm{S} 2$ to the $1961-1990$ climate normal were measured.

\subsection{Permafrost and seasonal frost conditions}

\subsubsection{Permafrost Conditions}

At Juvvass permafrost is present at the uppermost five borehole locations showing MAGSTs between $-2.4^{\circ} \mathrm{C}$ (PACE, $1894 \mathrm{~m}$ a.s.I.) and $-0.3^{\circ} \mathrm{C}$ (Juv-BH3, $1561 \mathrm{~m}$ a.s.I.). 10 The mean annual ground temperature at $10 \mathrm{~m}$ depth (MAGT $\left.T_{10}\right)$ increases from $-2.4^{\circ} \mathrm{C}$ (PACE) to $+0.7^{\circ} \mathrm{C}$ (Juv-BH6). A strong shift in MAGT 10 was measured between Juv$\mathrm{BH} 4$ and Juv-BH5 at the transition between permafrost and no-permafrost (Table 1), and attributed to absence of ground ice (Farbrot et al., 2011). Permafrost thickness at the PACE borehole was estimated to be approximately $380 \mathrm{~m}$ (Isaksen et al. 2001). 15 The active layer thickness (ALT) was ranging from $1.4 \mathrm{~m}$ (Juv-BH1) to $8.5 \mathrm{~m}$ (Juv-BH3) during the season 2008/2009. In the following season 2009/2010 the ALT at Juv-BH3 decreased to $6.8 \mathrm{~m}$, while at Juv-BH1 and PACE an increase of $10 \mathrm{~cm}$ was measured despite the colder air temperatures. Seasonal frost at Juv-BH5 and Juv-BH6 (Fig. 4b) reached down to approx. $4 \mathrm{~m}$ and $0.5 \mathrm{~m}$ (2.5 $\mathrm{m}$ in 2009/2010), respectively.

At Tron permafrost conditions are found at the uppermost borehole only (Tro-BH1, $1640 \mathrm{~m}$ a.s.l.) showing temperatures close to $0^{\circ} \mathrm{C}$ and clear signs of permafrost degradation (Fig. 4e). The MAGSTs (2008/2009) are all above freezing ranging from $+0.7^{\circ} \mathrm{C}$ to $+1.3^{\circ} \mathrm{C}$. At all boreholes the MAGST decreased in the following season and decreased to -0.3 at Tro-BH1 probably due to a thinner snow cover than the previous

\section{it increased to a slightly positive value during $2009 / 2010$.} it increased to a slightly positive value during 2009/2010. The increase of ALT from $10.7 \mathrm{~m}$ to $11.1 \mathrm{~m}$ (Fig. 4c) despite colder MAAT and MAGST implies the beginning of a

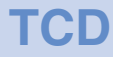

$5,811-854,2011$

\section{Temperature evolution modelling of permafrost and seasonal frost}

T. Hipp et al.

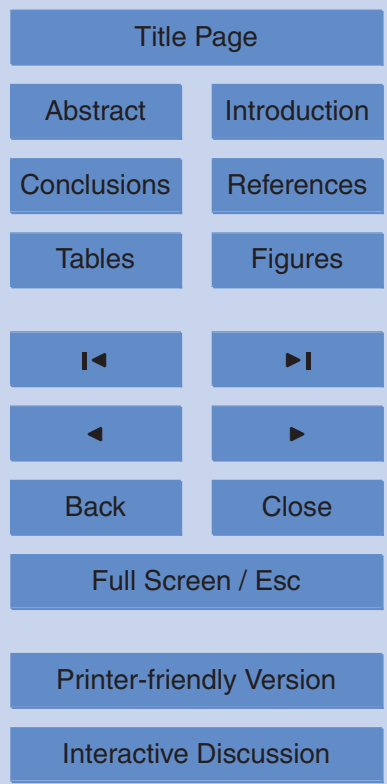


talik development at this site (Farbrot et al., 2011). Along the north slope of Tron, comparatively low MAGST of $-0.4^{\circ} \mathrm{C}$ and $-0.7^{\circ} \mathrm{C}$ were recorded by miniature temperature loggers at lower elevations of $1570 \mathrm{~m}$ and $1450 \mathrm{~m}$ a.s.l., respectively. This indicates the possible presence of permafrost on the north facing slope of the mountain massif 5 (Farbrot et al., 2011). Seasonal frost dominates at boreholes Tro-BH2 (Fig. 4f) and TroBH3 with depths of approx. $1.5 \mathrm{~m}$ and $2 \mathrm{~m}$ in 2008/2009 and $4 \mathrm{~m}$ and $2 \mathrm{~m}$ in 2009/2010, respectively.

Similarly, at Jetta permafrost conditions are present at the uppermost borehole (Jet$\mathrm{BH} 1,1560 \mathrm{~m}$ a.s.I.) with a MAGST of $-0.4^{\circ} \mathrm{C}$ and a MAGT 10 of $-0.8^{\circ} \mathrm{C}$ (Fig. 4C). The 10 further distribution of MAGSTs is depends on the snow cover. Due to a thick snow cover $(>140 \mathrm{~cm})$ at Jet-BH2 $\left(1450 \mathrm{~m}\right.$ a.s.I.) GSTs in both seasons $\left(+0.9^{\circ} \mathrm{C}\right)$ are higher than at Jet-BH3 $\left(+0.5\right.$ and $\left.-1.1^{\circ} \mathrm{C}\right)$ without snow cover at a much lower elevation $(1218 \mathrm{~m}$ a.s.l.). Seasonal frost reaches depths of approx. $6.5 \mathrm{~m}$ and $6 \mathrm{~m}$ in 2008/2009 and $6.5 \mathrm{~m}$ and $7.5 \mathrm{~m}$ in 2009/2010 at Jet-BH2 and Jet-BH3 (Fig. 4d), respectively.

\subsubsection{Correlation of GST to air temperature}

Coupling between the GST and $T_{\mathrm{AIR}}$ at each borehole site is essential for describing an appropriate upper boundary condition for the heat flow model. At the study sites this relationship varies strongly from borehole to borehole, depending on snow and surface cover (Fig. 3). Boreholes without significant snow cover $(<60 \mathrm{~cm})$ and block fields as surface cover (Juv-BH3, Juv-BH4, Jet-BH3) show a good linear correlation with $r^{2}>0.8$ (up to 0.95 at bedrock sites). However, the majority of boreholes are strongly affected by thick and long-lasting snow cover (Tro-BH1, Tro-BH2, Jet-BH1, Jet-BH2 and Juv$\mathrm{BH} 6)$ and therefore show a deviation of the GST from $T_{\text {AIR }}$ during the winter season resulting in $r^{2}$-values between 0.3 and 0.6 (Fig. 3).

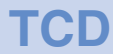

$5,811-854,2011$

\section{Temperature evolution modelling of permafrost and seasonal frost}

T. Hipp et al.

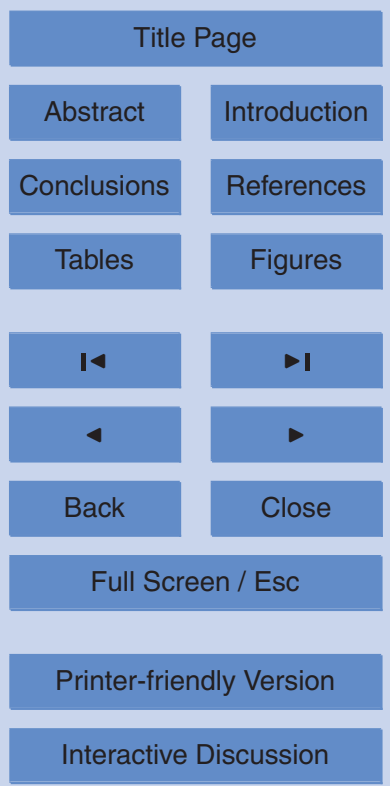




\subsubsection{Interannual Variation}

The borehole temperatures show different susceptibilities to inter-annual variability in climatic conditions due to their correlation of GST to air temperature (Fig. 3). Boreholes with a close atmosphere-ground surface coupling show much lower GSTs and

5 GTs in Season 2. The GST was $0.6^{\circ} \mathrm{C}$ at Juv-BH3 and even $2.1^{\circ} \mathrm{C}$ lower at the pure bedrock site Juv-BH4 than during Season 1 (Table 1). While Jet-BH2 shows a constant MAGST of $+0.9^{\circ} \mathrm{C}$ during both seasons due to snow cover, strong variations at Jet-BH3 with $+0.5^{\circ} \mathrm{C}$ during $\mathrm{S} 1$ and $-1.1^{\circ} \mathrm{C}$ during $\mathrm{S} 2$ (Table 1) demonstrate closer coupling between atmosphere and ground surface (Fig. 3).

10 At boreholes that show a similar snow cover during Season 1 and Season 2, the GST does not change significantly. However, at sites where the snow cover was much thicker in S1 compared to S2, a significantly lower GST in comparison to the previous year was measured.

\section{Methods}

\subsection{1-D numerical heat flux model}

For this study we used a one-dimensional transient heat flow model, which was applied in similar studies previously (Farbrot et al., 2007; Etzelmüller et al., 2011). Assuming heat conduction as the only process of energy transfer the model is solving the heat flux equation (Williams and Smith, 1989)

$20 \rho c \frac{\delta T}{\delta t}=-\frac{\delta}{\Delta z}\left(\frac{\delta T}{\delta z}\right)$

describing the evolution of the ground temperature $T$ over time $t$ and depth $z$, where heat capacity $c$, thermal conductivity $k$ and density $\rho$ are the main thermal properties of the ground. All borehole stratigraphies were implemented in the model with a spatial

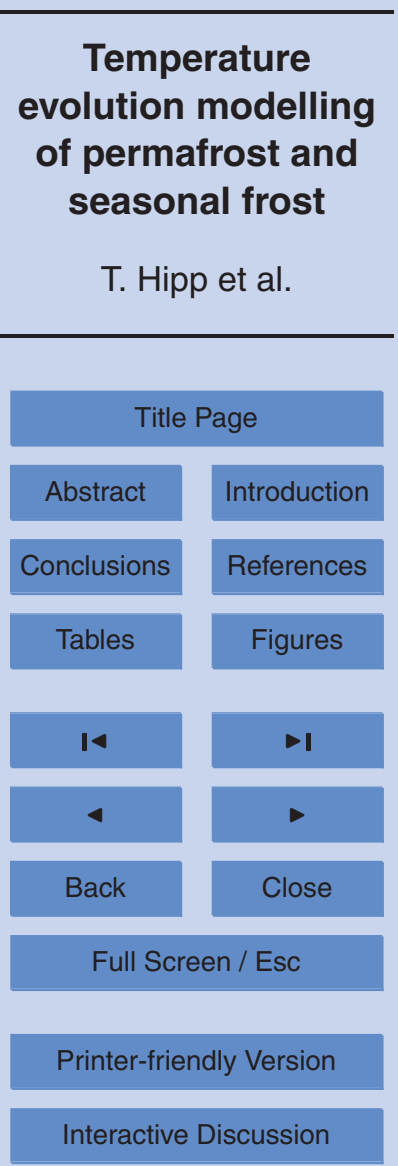


resolution of $\Delta z=0.1 \mathrm{~m}$ by assigning the ground thermal properties to the according depth of the discontinuity (Table 1). The heat flux Eq. (1) is then solved using finite differences along the borehole profile to a depth of $150 \mathrm{~m}$. The water content is implemented in the model as volumetric water content ( $V W C$ ), however, as a unique value

5 and does not change over time. The effect of latent heat due to freezing and thawing of the ground is accounted for by using the implementation of an apparent heat capacity. Any effects related to the advection of heat due to flow of ground water or of air in coarse-grained blockfields are not considered in the model.

\subsection{Model initialization and boundary conditions}

10 A geothermal heat flux of $Q_{\text {geo }}=50 \mathrm{~mW} \mathrm{~m}^{-2}$ (Isaksen et al., 2001) is used as lower boundary condition, while the GST is needed as upper boundary condition to run the model. Historical and future time series of GST were generated from the reconstructed $T_{\text {AIR }}$ and downscaled climate change scenarios respectively using $n$-factors. $N$-factors describe the coupling of atmosphere and ground surface by parameterizing the effect of snow cover and vegetation, thus we did not treat snow cover explicitly in the model. They were derived from measured GST and $T_{\text {AIR }}$ time series at each borehole individually by calculating the ratio of annual sums of freezing and thawing degree days of GST to those of $T_{\text {AIR }}$. Since the two monitored seasons show strong differences in snow cover and air temperature, mean values of $n_{F}$ and $n_{T}$ were used (Table 1), 20 implying that the range of snow and air temperature conditions during the two seasons represents the conditions dominating during at least the last decades.

For calibration and validation, the model was initialised using the first observed GT profile. For the modelling of permafrost history the model was initialized using the mean air temperature of the decade 1860-1870 (MA $\left.T_{1860}\right)$. At a first step the model 25 was forced with MAT $T_{1860}$ until a steady-state GT profile was achieved. In order to create initial condition including a typical seasonal cycle and AL development, the seasonal variation of $T_{\text {AIR }}$ was parameterized with a 2 nd order Fourier series fitted to the measured MDAT of 2008/2009 $\left(r^{2}>0.8\right)$ (Fig. 5). Using the first steady-state profile

\section{Temperature evolution modelling of permafrost and seasonal frost}

T. Hipp et al.

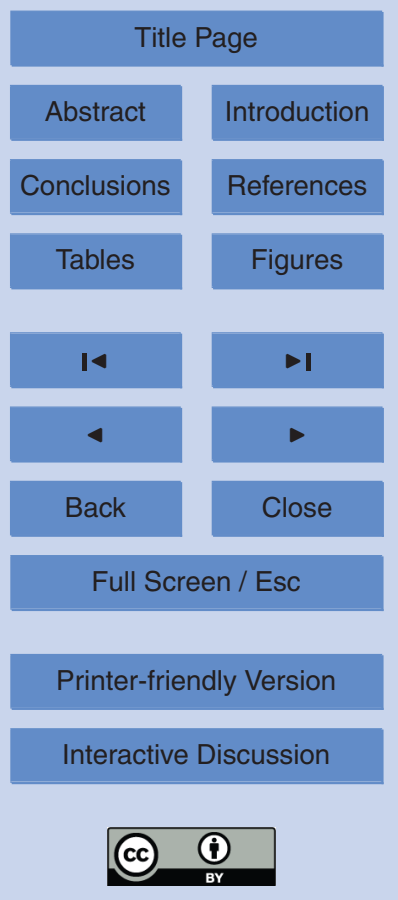


as initial condition, the model was run with the parameterized air temperature cycle until, again, steady-state conditions were achieved. Following this procedure, initial permafrost conditions including a seasonal cycle and an active layer could be generated for each instrumental borehole. The last profile created was then used as initial condition for the modelling of historic permafrost conditions.

\subsection{Model calibration and validation}

Measured values for thermal conductivity and density of Juv-BH5 were measured at the Norwegian Geological Survey (NGU). Further parameter values were taken from literature (Williams and Smith, 1989) and later on manually adjusted during calibration to achieve good agreement between observed and modelled GT (Table 2). A time series of measured soil moisture in the vicinity of some sites (Juv-BH1, Tro-BH1) served as an estimate for the water content (O. Humlum, personal communication, 2011).

The model was calibrated on all of the boreholes in this study in order to adjust the ground properties (Table 2) and therefore reproduce the measured GTs with highest possible accuracy. The calibration was conducted by running the model with measured daily ground surface temperature from season 2008/2009 as upper boundary condition. The data from 2009/2010 served as validation period to assess the model accuracy. At the PACE borehole the time series was divided into a calibration period from 1999 to 2007 and a validation period from 2008 to 2010.

20 The appropriateness of the $n$-factor approach for GST depends on the presence and duration of snow cover as well as the surface cover characteristics (coarse blocks, vegetation, bedrock) at the site. To validate the reliability of the GST model, it was run with the daily air temperature from the period 2008-2010 and compared to the measured GSTs. For most of the boreholes a good correspondence between modelled 25 and measured GST could be found with $r^{2}$-values $>0.8$ (except Tro-BH1 with $r^{2}=0.76$ ) (Fig. 6). Correlation values of $r^{2}>0.90$ were achieved at bedrock sites where hardly any snow cover is present (Juv-BH4, Jet-BH3). Sites with a pronounced snow cover (Tro-BH1, Jet-BH1) and/or a coarse block cover (PACE, Juv-BH1) yield lower $r^{2}$-values

\section{Temperature evolution modelling of permafrost and seasonal frost}

T. Hipp et al.

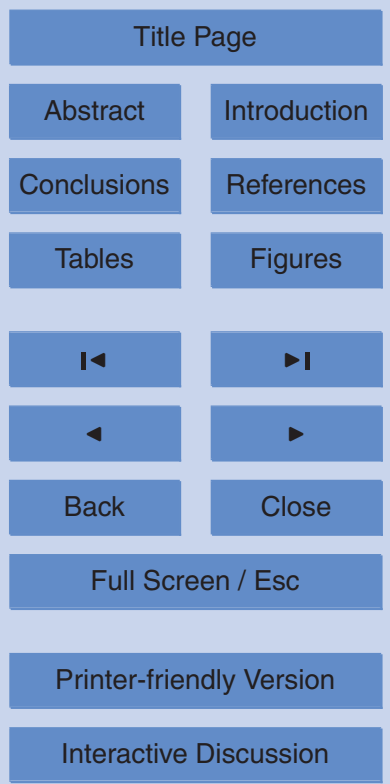


around 0.77 to 0.89 (Fig. 6). However, the GST model could reproduce the typical insulating effect of a thick snow successfully, as shown in Fig. 3. The RMSE is ranging between $1.2^{\circ} \mathrm{C}$ at bedrock sites to $2.7^{\circ} \mathrm{C}$ at sites with blockfields and/or snow cover (Table 3).

5 After fine-adjusting the ground parameters, the calibrated borehole models reproduce the measured GTs with high accuracies showing $r^{2}$-values $>0.96$ (except Juv$\mathrm{BH} 6$ ) and a RMSE ranging from $0.13^{\circ} \mathrm{C}$ to $0.89^{\circ} \mathrm{C}$ (Table 3, Fig. 7b).

\subsection{Historic and future temperature data}

Historic air temperature from 1860 to 2008 for all borehole sites were generated by 10 the following procedure: Mean daily air temperatures (MDAT) are available as $1 \mathrm{~km}$ resolution maps (MDA $T_{\text {grid }}$ ) covering entire Norway, and which are gridded by interpolating station observations (Mohr, 2009). Secondly, standardized air temperature series of monthly values have been generated for regions of Norway showing a fairly homogenous air temperature variability on longer time-scales (Hanssen-Bauer and 15 Nordli, 1998). Based on linear regression of MDAT measured at the borehole (MDA $T_{\mathrm{BH}}$ ) and the MDA $T_{\text {grid }}$, MDAT time series from 1957 until 2008 were generated for the uppermost boreholes including PACE, Juv-BH1, Jet-BH1 and Tro-BH1. From these series, mean monthly air temperature values $\left(\mathrm{MMA} T_{\mathrm{BH}}\right)$ and their associated standard deviations (MSTDEV $\mathrm{BH}_{\mathrm{BH}}$ ) were calculated for the normal period 1961-1990. For the 20 uppermost boreholes a long reconstructed time series of MMAT values from 18601956 could be generated following the method described by (Hanssen-Bauer, 2005) (Fig. 8a):

MMAT $=$ MMAT $_{B H}+$ Standardized regional value $\cdot$ MSTDEV $_{B H}$

The altitudinal lapse rate of $0.5^{\circ} \mathrm{C} 100 \mathrm{~m}^{-1}$ and $0.8^{\circ} \mathrm{C} 100 \mathrm{~m}^{-1}$ measured at Juvvass 25 and Tron, respectively, was used to generate long air temperature time series for all other boreholes (Table 4). The historic air temperature series used as input data for the

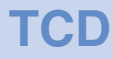

5, 811-854, 2011

\section{Temperature evolution modelling of permafrost and seasonal frost}

T. Hipp et al.

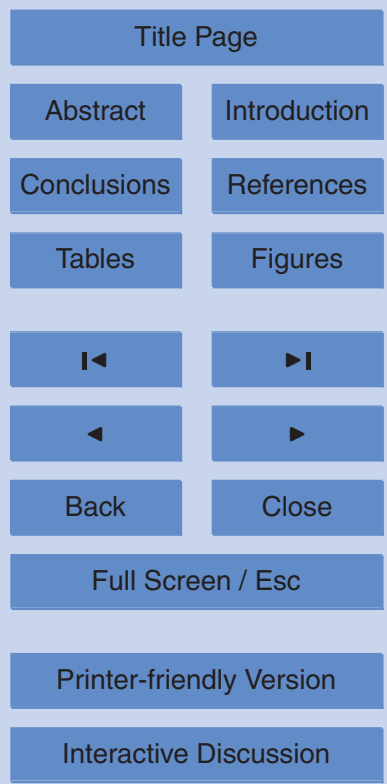


modelling therefore consists of MMAT values until 2008 and measured MDAT values for 2008-2010.

For the climate change model runs, the rather moderate A1B climate change scenario was chosen. The A1B scenario assumes balanced use of all energy sources 5 with a increase in renewable energy sources, therefore assuming a decrease of $\mathrm{CO}_{2}$ emissions by the mid of the 21st century (IPCC, 2007). The likely range of the global mean temperature change from 1990 to 2100 of the A1B scenario is between $+1.7^{\circ} \mathrm{C}$ and $+4.4^{\circ} \mathrm{C}$, with a best estimate of $+2.8^{\circ} \mathrm{C}$ (IPCC, 2007).

Data from an ensemble of 20 different GCM runs were downscaled to the nearby 10 weather station Fokstugu (Benestad, 2010; Benestad, 2005) and used to drive the ground heat flux model. The measured daily air temperature data at each borehole was correlated to Fokstugu yielding an $r^{2}>0.9$. This relationship allowed the construction of air temperature scenarios for each borehole site individually from 2010 until 2100 (Fig. 8a).

154 Results

\subsection{Historical and future temperature trends}

The historical air temperature series shows a warming of $1.6^{\circ} \mathrm{C}$ and $2{ }^{\circ} \mathrm{C}$ in TAIR from 1860 until 2009 (resulting in a warming rate of $+1.1^{\circ} \mathrm{C}(100 \mathrm{a})-1$ and $\left.+1.3^{\circ} \mathrm{C}(100 \mathrm{a})-1\right)$ at Juvvass and Tron respectively (Table 4). At both sites only positive deviations of TAIR to the climate normal 1961-1990 were observed during the last decade (Fig. 8b,c,), while at Tron the warming appears to be stronger (Fig. 8c). In the period 1860s until $2000 / 2009$ the strongest warming occurred during spring with $+2.1^{\circ} \mathrm{C}$ at both sites. At Juvvasshøe the lowest warming occurred in winter with $+0.9^{\circ} \mathrm{C}$. The continental site Tron, however, shows strong warming of air temperature in winter and spring as well with +1.8 and $+1.9^{\circ} \mathrm{C}$ for winter and fall, respectively.

The median of the downscaled future temperatures indicates a further warming of

\section{Temperature evolution modelling of permafrost and seasonal frost}

T. Hipp et al.

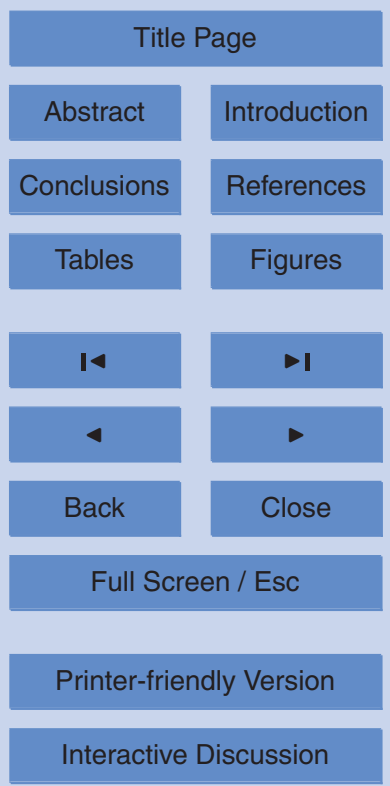


$+2.8^{\circ} \mathrm{C}$ of the decadal means $2001 / 2010$ until $2091 / 2100$. The 10 th percentile shows the same warming trend, the 90th percentile, however, shows an increase of $+3.3^{\circ} \mathrm{C}$ (Fig. 8a). The deviation of the median to the climate normal 1961-1990 amounts to $+3.8^{\circ} \mathrm{C}$ and $+4.2^{\circ} \mathrm{C}$ at Juvvass (Fig. $8 \mathrm{~b}$ ) and Tron (Fig. 8c), respectively.

\section{$5 \quad 4.2$ Historic permafrost development}

\subsubsection{Mountain permafrost after the Little Ice Age}

From the initial conditions rough estimates for the lower limit of mountain permafrost can be taken. The modelling results suggests that permafrost of $20 \mathrm{~m}$ thickness was present at Juvvass even at the lowermost borehole (1314 $\mathrm{m}$ a.s.l.) at the beginning of the model period at 1860 . The ALT is ranging from $0.5 \mathrm{~m}$ at $1900 \mathrm{~m}$ (Juv-BH1) to $\mathrm{c} .3 \mathrm{~m}$ at $1314 \mathrm{~m}$ a.s.I (Juv-BH6). The greatest ALT at Juvvass is modelled for the bedrock site (Juv-BH4) with an ALT of close to $4 \mathrm{~m}$. Less extensive permafrost thicknesses $(<90 \mathrm{~m})$ and higher ALT (1.3-6.1 m) were modelled for the more continental site at Tronfjell. However, at this site the lower limit of permafrost was modelled to have been lower than $1290 \mathrm{~m}$ a.s.l.

\subsubsection{Ground temperatures}

For the period from 1860 to 2009 increasing GTs at all depths were modelled. However, at all boreholes the most significant increase in GTs is restricted to the last two decades only. The model results show an increase in GT at $10 \mathrm{~m}$ depth since the 1860 s from $+0.9^{\circ} \mathrm{C}$ to $+1.5^{\circ} \mathrm{C}$ at Juvvass. At Tron, however, a much lower increase of $+0.1^{\circ} \mathrm{C}$ to $+0.7^{\circ} \mathrm{C}$ was modelled. GTs at $100 \mathrm{~m}$ depth increased by $+0.4^{\circ} \mathrm{C}$ to $+1^{\circ} \mathrm{C}$ at Juvvass and $+0.1^{\circ} \mathrm{C}$ to $+0.4^{\circ} \mathrm{C}$ at Tron. The strongest warming was modelled at the bedrock borehole (Juv-BH4) with $+1.5^{\circ} \mathrm{C}$ and $+0.5^{\circ} \mathrm{C}$ at $10 \mathrm{~m}$ and $100 \mathrm{~m}$ depth, respectively.

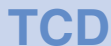

$5,811-854,2011$

\section{Temperature evolution modelling of permafrost and seasonal frost}

T. Hipp et al.

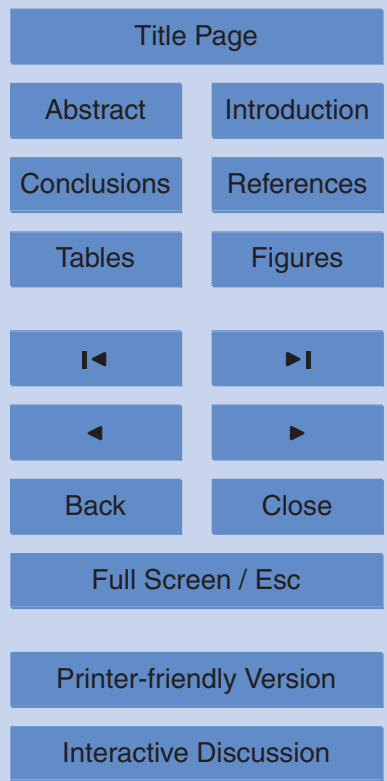




\subsubsection{Active layer thickness}

Depending on location, elevation and stratigraphy, different ALT developments are suggested by the model results. However, a characteristic pattern can be observed at all boreholes, with a comparatively slow ALT increase from the 5-year mean 1860/1864

5 until the end of the 20th century (1995/1999) and accelerated thickening rates during the decade 2000-2009. At Juvvass the lowermost borehole (Juv-BH6) shows a very rapid ALT increase and permafrost degradation prior to the end of the 19th century. The 20th century increase in ALT at the other boreholes was only $+0.2 \mathrm{~m}(24 \%$,

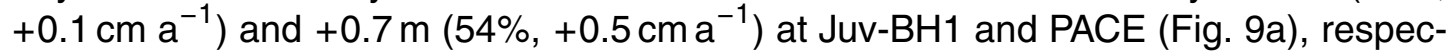
10 tively. The lower boreholes Juv-BH3 and Juv-BH4 show a stronger increase of ALT in the same period with $+2.3 \mathrm{~m}\left(68 \%,+1.6 \mathrm{~cm} \mathrm{a}^{-1}\right)$ and $+2.4 \mathrm{~m}\left(65 \%,+1.7 \mathrm{~cm} \mathrm{a}^{-1}\right)$, respectively. The model suggests accelerated ALT increase at all boreholes over the last 10 years with $+0.2 \mathrm{~m}\left(20 \%,+2 \mathrm{~cm} \mathrm{a}^{-1}\right),+0.7 \mathrm{~m}\left(35 \%,+7 \mathrm{~cm} \mathrm{a}^{-1}\right),+2.6 \mathrm{~m}(46 \%$, $\left.+26 \mathrm{~cm} \mathrm{a}^{-1}\right)$ and $+2.4 \mathrm{~m}\left(40 \%,+24 \mathrm{~cm} \mathrm{a}^{-1}\right)$ at Juv-BH1, PACE, Juv-BH3 and Juv-BH4, 15 respectively.

The PACE borehole shows higher mean inter-annual variation of ALT than Juv-BH1 with $+40 \mathrm{cma}^{-1}$ and $+20 \mathrm{cma}^{-1}$, respectively. Although Juv-BH3 was drilled in coarse material and Juv-BH4 in bedrock they show a similar ALT development, the latter however, having continuously larger ALT (average $0.4 \mathrm{~m}$ ) and a much higher mean inter20 annual variation of $70 \mathrm{~cm} \mathrm{a}^{-1}$ compared to $30 \mathrm{~cm} \mathrm{a}^{-1}$.

As on Jetta all boreholes are drilled in bedrock, the ALT is more sensitive to climate variations, and a more rapid increase during the last 150 years was modelled. From 1870 to the end of the 1980s the ALT increased by $+1.1 \mathrm{~m}\left(26 \%,+1 \mathrm{~cm} \mathrm{a}^{-1}\right)$ and almost $+2.2 \mathrm{~m}\left(40 \%,+2 \mathrm{~cm} \mathrm{a}^{-1}\right)$ at Jet-BH1 and Jet-BH3, respectively. During the 25 period 1990 until 2010 the strongest increase of $A L T$ of $+2.7 \mathrm{~m}\left(50 \%,+14 \mathrm{~cm} \mathrm{a}^{-1}\right)$ was modelled at Jet-BH1, while permafrost thawed completely at Jet-BH3 (Fig. 9b).

At Tron, accelerated increases of ALT was modelled. The ALT at Tro-BH1 increased by $+1.1 \mathrm{~m}\left(110 \%,+0.8 \mathrm{~cm} \mathrm{a}^{-1}\right)$ until the end of the 20th century (Fig. 9c). However,

5, 811-854, 2011

\section{Temperature evolution modelling \\ of permafrost and seasonal frost}

T. Hipp et al.

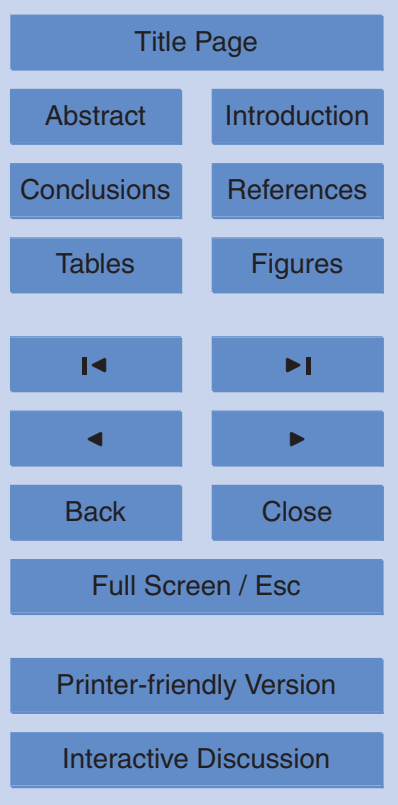

Interactive Discussion 
within the last decade only, permafrost was warming rapidly at this site reaching an ALT of $10-11 \mathrm{~m}$ as measured today, resulting in an ALT increase of nearly $+9 \mathrm{~m}(430 \%$, $\left.+87 \mathrm{~cm} \mathrm{a}^{-1}\right)$. This development agrees with obeservations indicating the beginning of a talik development (Fig. 4e) (Farbrot et al., 2011)

\section{4.3 Future permafrost development}

According to projected temperatures, the GT warming trend modeled will continue beyond that found for 2000-2009. The model suggests that GTs at Juv-BH1 will increase by $+1.9^{\circ} \mathrm{C}$ and $+1.1^{\circ} \mathrm{C}$ at $30 \mathrm{~m}$ and $100 \mathrm{~m}$ depth until 2100 , respectively. Juv-BH4 shows the same warming at $100 \mathrm{~m}$ depth, however, a much more pronounced increase in GT at $30 \mathrm{~m}$ with $+2.6^{\circ} \mathrm{C}$. The model results indicate that at an elevation of $1900 \mathrm{~m}$ a.s.l. permafrost shows strong signs of degradation or even talik development by the end of this century. Permafrost at lower elevations (Juv-BH3 and Juv-BH4) degrades completely before 2050 (Fig. 9a). At the bedrock site at Jetta the rapid AL thickening rates at Jet-BH1 will continue and the development of a talik until the end of the 2020s a.s.l. by the end of the last century, permafrost at the summit reaches the current state of degradation with an ALT of more than 11m (Fig. 9c).

Running the model with the 90th and 10th percentiles of the downscaled temperature ensemble gives an estimation of the possible range of developments. The 90th percentile causes a fast degradation and thawing of permafrost at all boreholes by latest mid of this century (Fig. 9a). Assuming the very moderate climate models (10th percentile) permafrost at Juv-BH1 and PACE is warming at a slow rate, however, no degradation was modelled.

Although the air temperature increase in the climate change scenario shows a linear development and even a decrease in the warming rate (Fig. 8a), a non-linear response of ALT and GTs was modelled at all sites running the model with the median of the climate change models (Fig. 9). The ALT of Juv-BH1 increases linearly by another $70 \mathrm{~cm}$ from 2010 until mid 2070s. Although the climate change scenario includes a

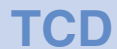

5, 811-854, 2011

\section{Temperature evolution modelling of permafrost and seasonal frost}

T. Hipp et al.

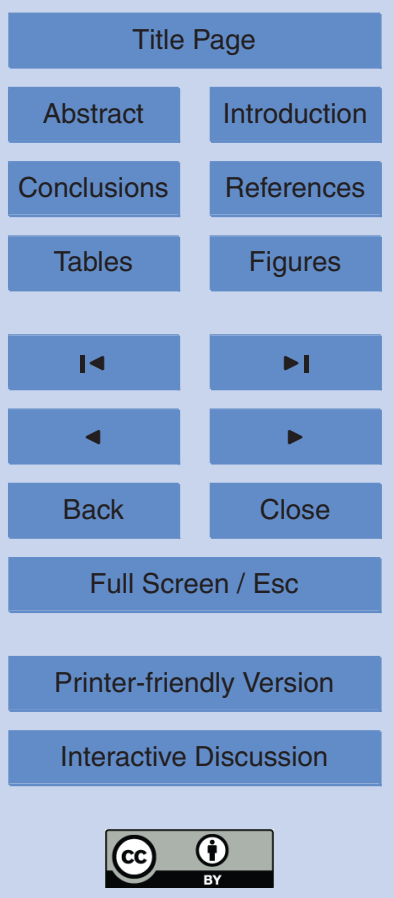


decrease in the warming rate at this point, thereafter a rapid degradation of permafrost takes place until the end of this century with a linear increase of ALT by $>40 \mathrm{~cm} \mathrm{a}^{-1}$. A similar development can be observed at the PACE borehole, however, with higher thickening rates and a permafrost degradation and thawing at the mid 2060s.

\section{Discussion}

\subsection{Model uncertainties due to snow cover and water content variability}

A major source of uncertainties is the coupling between air and ground surface temperature. In this study GSTs are derived from the air temperature using $n$-factors that stay constant throughout the modelled period, which of course is an over-simplification, as snow is not treated explicitly (Engelhardt et al., 2010; Luetschg et al., 2008). However, the strong variation of the two monitored season in terms of air temperature and snow cover (Table 1) made it possible to estimate the error that can be expected from $n$-factors that do not accurately represent the snow cover of each year.

The GSTs of Season 1 were modelled using both the "correct" $n$-factors (S1_nf1) 15 and the "wrong" $n$-factors which correspond to Season 2 (S1_nf2). This procedure was repeated for the generation of GSTs of Season 2 with the "correct" $n$-factors (S2_nf2) and "wrong" $n$-factors (S2_nf1). Each model run, S1_nf2 and S2_nf1, was then compared to the measured data of the according season and the RMSE was calculated. The RMSE and MAGST, were compared to the original model runs (S1_nf1, S2_nf2) and the differences ( $\triangle$ MAGST, $\triangle \mathrm{RMSE}$ ) were calculated (Table 5 ). In average, the RMSE increases by $0.1^{\circ} \mathrm{C}$ to $0.7^{\circ} \mathrm{C}$ when running the GST model with the $n$-factors of the other season. Further, in average the absolute changes of the GSTs due to 'wrong' $n$-factors are comparatively low with RMSE-values in the range of 0.4 to 0.7 .

High values of $\triangle$ MAGST correspond to boreholes that show a shallower and varying 25 snow cover as well as a complex surface cover (e.g. Juv-BH1, Juv-BH3 and Juv-BH5). At these sites small changes in snow depth have a large effect on the GST. However,

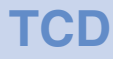

$5,811-854,2011$

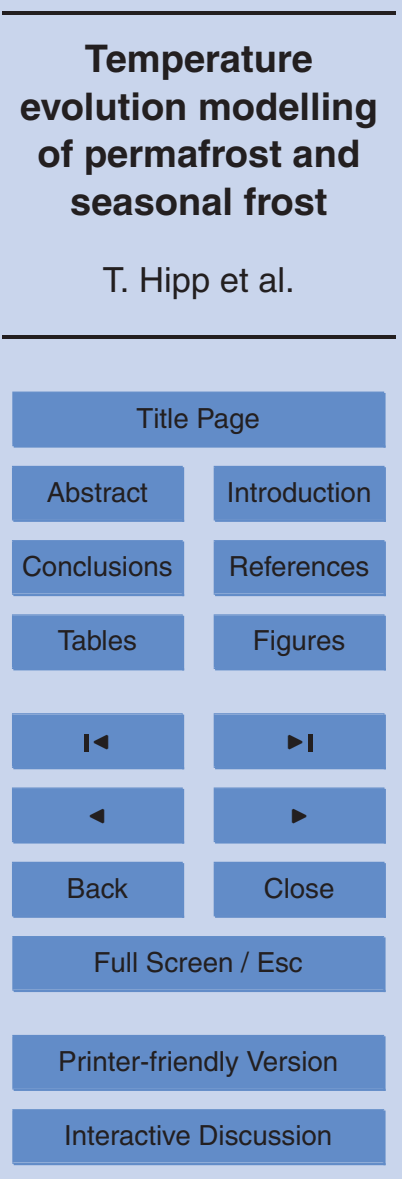


the same small change in snow cover does not have a strong effect on the GST of a site with an annual maximum snow cover exceeding $140 \mathrm{~cm}$ (e.g. Tro-BH2 and Jet-BH1), since $80 \mathrm{~cm}$ of snow are generally sufficient to insulate the ground surface temperature from the air temperature. These sites therefore are less sensitive to variations in $n$ -

5 factors. Compared to other sources of error, e.g. due to uncertainties in the climate change scenarios, we consider these errors due to constant $n$-factors as small.

The model reproduced the measured GTs with good accuracy regardless of the water content at the borehole sites. However, at sites where water content is high, deviations occurred during periods of melting and freezing, where measured data exhibit 10 the presence of a zero-curtain, while the model results do not (Fig. 6). Considering that both soil water content and snow conditions on the long-term are afflicted with major uncertainties, we believe that the described shortcomings are of minor importance.

\subsection{Model uncertainties due to climate change scenarios}

One major source of uncertainty is related to the spread of projected temperature evo15 lution according to the multi-model ensemble. In order to quantify the effects on modelled ALT and permafrost warming, the development of ALT until 2100 was simulated using projected temperatures ranging from from the 10th to the 90th percentile in steps of five. From these results, we identify the percentiles which are associated with disappearance of an AL in the years 2050 and 2100, respectively. This analysis in turn 20 is used as an indication of the likelihood that permafrost at Juv-BH1 and PACE will be replaced by a talik at 2050 and 2100 (Fig. 10).

At the PACE borehole a talik development by 2100 was modelled already using the 25th percentile resulting in a high probability of $70-75 \%$. Using the classification proposed by the IPCC (IPCC, 2007) it is likely for this scenario to occur. However, at 25 Juv-BH1 a talik will be developed in 2100 with a probability of $50-55 \%$, which makes it about as likely to occur as not. The probability that a talik is present at these two boreholes by the year 2050 is unlikely at both sites. The probabilities are at $35-40 \%$ and 20-25\% for PACE and Juv-BH1, respectively (Fig. 10). This means that above $1800 \mathrm{~m}$

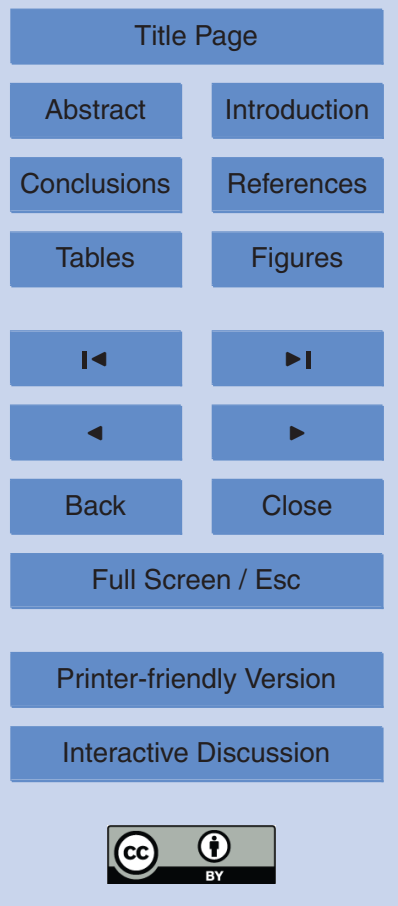


a.s.l. where stable and continuous mountain permafrost is present today, discontinuous mountain permafrost is to be expected by the end of the 21st century. Then the pattern of permafrost would be governed by ground ice content and snow conditions.

\subsection{Influence of ground properties on thermal regime}

5 The thermal regime reacted differently to a changing climate due to differences in surface material, ground properties and thus soil water content. The absolute change of ALT from one year to the next was calculated and averaged for the period 1860-2009 for all boreholes at Juvvasshøe. Borehole Juv-BH4, which does not have significant snow cover and is located in bedrock shows the highest mean variation of $0.68 \mathrm{~m} \mathrm{a}^{-1}$ 10 and a strong correlation to the mean inter-annual variation of summer $T_{\text {AIR }}\left(r^{2}=0.7\right)$. Much lower interannual ALT variation of $0.2 \mathrm{~m} \mathrm{a}^{-1}-0.3 \mathrm{~m} \mathrm{a}^{-1}$ and $r^{2}$-values of $0.25-$ 0.40 were calculated for boreholes covered by block fields. This suggests that the block field acts as a buffer layer retarding and dampening the effect of the air temperature on the GTs. At Juv-BH4, however, no such buffer layer exists causing a direct 15 response of the ALT to changes in $T_{\text {AIR }}$. In eastern Norway, Juliussen and Humlum (2008) clearly demonstrated these effects in block fields, while recently Gubler et al. ((2011) showed large variability of ground surface temperatures due to surface material cover in the Alps. Gruber and Hoelzle (2008) found that ground temperatures in block fields could be modelled by attributing low thermal conductivities for these layers.

20 Despite their vicinity, the boreholes PACE and Juv-BH1 show a different thermal regime and ALT development in past and future due to differences in water content. According to the calibrated model, Juv-BH1 has a VWC $\leq 15 \%$, the PACE borehole has a $\mathrm{VWC} \leq 5 \%$. Therefore, a large part of the energy transferred into the ground at Juv-BH1 is consumed for melting processes. This explains the much lower inter 25 annual variability in ALT and the less pronounced increase in AL in past and future. Furthermore, the non-linear response in ALT with the sudden degradation is related to the melting of ice within the ground. After melting of ground ice, more energy is available to effectively warm the ground. Similar results are known from North-America 829

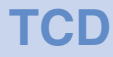

$5,811-854,2011$

\section{Temperature evolution modelling of permafrost and seasonal frost}

T. Hipp et al.

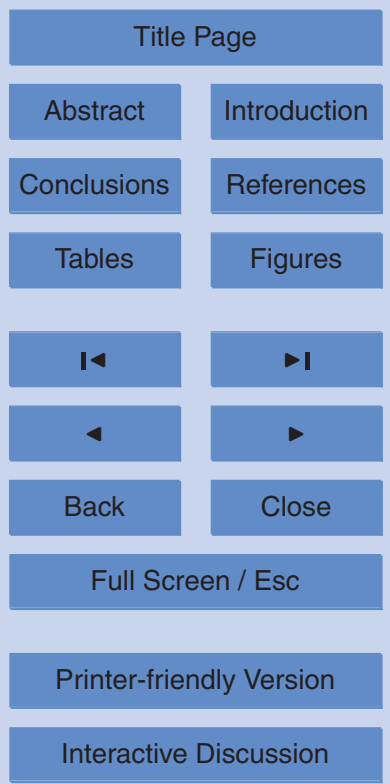

Interactive Discussion 
(Smith et al., 2010) and Russia (Romanovsky et al., 2010), where the response of GT and ALT to climate warming the last 50 years are clearly attributable to water content, soil type and deviations to the $0^{\circ}$ isotherm in the ground.

Similar results have been found comparing the impact of the extreme summer of 52003 on the ALT of bedrock and blockfield sites in the Swiss Alps (Vonder Mühll et al., 2007). The ALT of the bedrock borehole on Schilthorn directly increased from around 4.9 to $9 \mathrm{~m}$. The subsequent years, however, the ALT decreased again to a depth of $4.8 \mathrm{~m}$, thus close the value of the previous years. The ALT of the ice-rich rock glacier of Murtèl-Corvatsch, however, was not severely affected by the warm summer showing increase of only $11 \mathrm{~cm}$ compared to the previous year (Vonder Mühll et al., 2007).

Several studies have tried to quantify the impact of climate change on permafrost conditions, distribution and ALT. Stendel and Christensen (2002) predicted a general increase of ALT of up to $30-40 \%$ until the end of the 21st century in the Northern Hemisphere. Comparably, Zhang et al. (2008) estimated the ALT increase in Canada to $1514-30 \%$ by 2050 compared to a permafrost baseline in the 1990s. For Svalbard, similar changes for the ALT evolution during the 21st century were modelled (Etzelmüller et al., 2011). In our study the ALT increased by 65 to $180 \%$ at the boreholes where permafrost still is expected by 2050. Even the results using the 10th percentile of the climate change models indicate an ALT increase of $44 \%$ at the PACE borehole. This implies a high sensitivity of warm mountain permafrost to climate change, comparable to coastal areas on e.g. Svalbard (Etzelmüller et al., 2011). Furthermore, many of the above mentioned assessements were made for Arctic lowlands, where large areas with organic components are present. Organic components in the near-surface layer are known to effectively damp the GT response to climate perturbations (Williams and 25 Smith, 1989). In mountain areas, significant accumulation of organic material is seldom and restricted to special topographic and geomorphic settings. However, block fields might have an effect similar to that of organic material in Arctic lowlands, i.e. retarding the GT-response to climate signals and cooling the ground, as discussed above.

\section{Temperature evolution modelling of permafrost and seasonal frost}

T. Hipp et al.

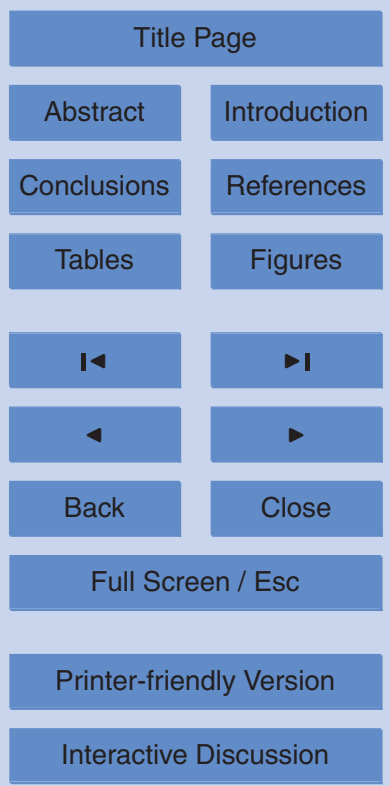




\subsection{Implications of the model results to geomorphological and geotechnical processes}

The modelled past and possible future changes in GT and ALT have certain geomorphological and geotechnical implications and in principle open for a discussion of a 5 wide range of topics, as the ground thermal regime is a major controlling factor for geomorphological processes and landscape development (Berthling and Etzelmüller, 2011). This study clearly demonstrates a major change in ground thermal regime since the end of the LIA. At that time, sporadic to discontinuous permafrost conditions seem to have been more widespread at elevations of around $1300 \mathrm{~m}$ a.s.l., where we 10 presently only find permafrost at isolated patches (Sollid et al., 2003). This translates to the permafrost limit being approximately $200 \mathrm{~m}$ lower during the LIA than toady. At Juvass, this zone between $1300 \mathrm{~m}$ a.s.l. up to $1500 \mathrm{~m}$ a.s.l. is dominated by block lobes, which may be inactive today, but witness of an earlier high-active periglacial environment. In contrast, climate warming would move this zone further up-slope, and 15 this study indicates that the lower limit of discontinuous permafrost could rise up to above $1800 \mathrm{~m}$ a.s.I., which means c. $250 \mathrm{~m}$. With such an scenario, major changes in periglacial processes can be anticipated.

One of the processes possible leading to major impacts are the geotechnical properties of rock walls. It is well-documented that permafrost and thus possible ice in joints and crevasses stabilises rock walls (Gruber et al., 2004a). The relation between rock wall stability and ice temperature in clefts was clearly demonstrated using centrifuge modelling techniques (Davies et al., 2001). It is obvious, that rock walls de-stabilises with increasing temperatures, and are especially vulnerable at rock wall temperatures between $-1.5^{\circ} \mathrm{C}$ and $0{ }^{\circ} \mathrm{C}$. In our study, at all of the borehole sites a non-linear re25 sponse to a comparatively linear climate warming trend was modelled. This suggests, that after the melt of ground ice permafrost degradation can occur rapidly and within a short time span. The degradation at the highest boreholes in flat terrain is predicted to occur by the end of this century (Fig. 9). However, due to low water content, exposure

\section{Temperature evolution modelling of permafrost and seasonal frost}

T. Hipp et al.

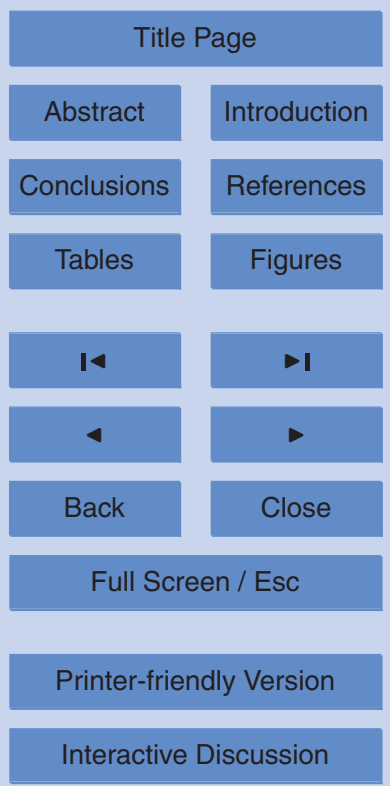


and bedrock conditions, rock walls are even more sensitive to climate warming. This implies that e.g. on a south facing rock wall at a similar elevation, the starting point of degradation might occur much earlier.

The model results using the 10th and 90th percentile of the air temperature scenar5 ios, indicate a possible range of permafrost developments (Fig. 9a). The ALT development indicated by the 10th percentile could represent the warmer conditions in a steep south facing slope or rock wall, while a north facing rock wall could show the ALT development predicted by the 90th percentile. This would cause strong gradients between these two expositions and an early and quick permafrost degradation on south facing 10 rock walls.

The strong warming dynamic of mountain permafrost in steep terrain has direct implications for slope stability, possibly causing increasing the frequencies of rock fall events and larger landslides. In addition, the long period of stable permafrost and a sudden and quick degradation results in challenges for geo-engineering, natural haz15 ard prediction and mitigation.

\section{Conclusions}

From this study the following main conclusions are drawn:

- During the Little Ice Age the lower limit of permafrost was probably about $200 \mathrm{~m}$ lower than today, and climate warming towards the end of the 21st century would further increase this limit by about $250 \mathrm{~m}$.

- Since roughly the end of the Little Ice Age (late 19th century) until today, ground temperatures at $10 \mathrm{~m}$ depth increased by around $+0.9^{\circ} \mathrm{C}$ to $+1.5^{\circ} \mathrm{C}$. Furthermore, the largest part of this warming occurred since around 1990.

- During the time period 1860 to 1990 a comparatively small increase in active layer thickness was modelled in the areas where permafrost exists today. Since

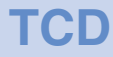

$5,811-854,2011$

\section{Temperature evolution modelling \\ of permafrost and seasonal frost}

T. Hipp et al.

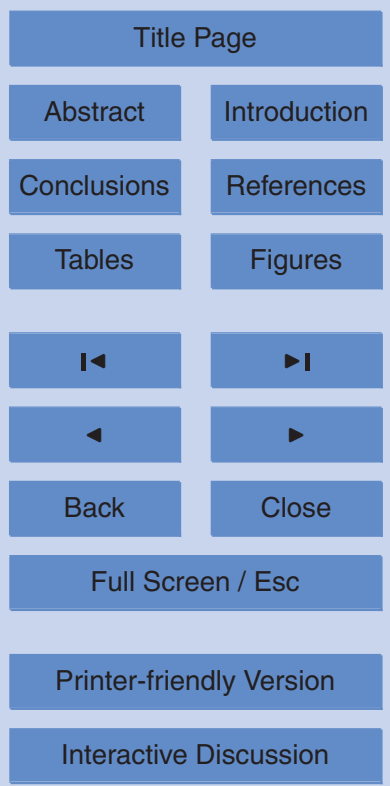


c. 1990 the increase of active layer thickness was substantial with rates ranging from $+2 \mathrm{~cm} \mathrm{a}^{-1}$ to $+26 \mathrm{~cm} \mathrm{a}^{-1}(20-430 \%)$.

- The assessement of future ground temperatures suggests a shift of the lower permafrost limit to higher elevations and the degradation of permafrost at most of the sites. Forcing the model with the median of the projected temperature ensemble, by the end of this century also the highest boreholes (Juv-BH1, PACE) would be subjected to permafrost degradation with deep active layers or even the development of a talik. This implies an upward shift of the lower permafrost limit to around $1900 \mathrm{~m}$ a.s.l. or even higher.

- Simulated ground temperatures at bedrock sites are generally more sensitive to climate change than those at sites within blockfields or finer-grained sediment cover. Especially block fields represent a thermal buffer, in agreement with results of other studies.

- Permafrost partly exhibits large thermal inertia with only slowly increasing active layer thickness until the melt of ground ice. Thereafter, degradation occurs within a short time period.

- The warming trend of permafrost at high elevations in combination with the high sensitivity of bedrock sites can have a significant effect on the stability of steep slopes and rock walls, which are common at Juvvasshøe in the zone between 1900-2400 m a.s.l.

Acknowledgements. This study was an integral part of the CRYOLINK project ("Permafrost and seasonal frost in Southern Norway") financed by the Norwegian Research Council (grant number 185987/V30) and the Department of Geosciences, University of Oslo (UiO). Special thanks go to Rune S. Ødegård from the University College in Gjøvik, Norway, for crucial support 25 in field logistics, especially in relation with establishing of the borehole network. Ketil Isaksen (Norwegian Meteorological Institute, Norway) is thanked also for valuable logistical support and providing updated temperature records from the PACE boreholes. R. Benestad kindly provided 
an empirically down-scaled GCM modelling ensemble from Fokkstua, southern Norway. Kjersti Gisnås (UiO) contributed during field work. Several land owners at Tron and Juvvass accepted drilling and instrumentation on their properties. The Geological Survey of Norway (NGU) did the measurements of density and thermal characteristics of the samples from the bedrock borehole 5 cores retrieved from the Juvvass (BH5) and Jetta boreholes. We want to thank all mentioned individuals and institutions.

\section{References}

Benestad, R. E.: Climate change scenarios for northern Europe from multi-model IPCC AR4 climate simulations, Geophys. Res. Lett., 32, L17704, doi:10.1029/2005GL023401, 2005.

Benestad, R. E.: A new global set of downscaled temperature scenarios, Journal of Climate, doi:10.1175/2010JCLI3687.1, 2010.

Berthling, I. and Etzelmüller, B.: The concept of cryo-conditioning in landscape evolution, Quat. Res., doi:10.1016/j.yqres.2010.12.011, 2011.

Biesinger, Z., Rastetter, E. B., and Kwiatkowski, B. L.: Hourly and daily models of active layer evolution in arctic soils, Ecol. Model., 206, 131-146, 2007.

Burn, C. R. and Zhang, Y.: Permafrost and climate change at Herschel Island (Qikiqtaruq), Yukon Territory, Canada, J. Geophys. Res.-Earth Surf., 114, F02001,, doi:10.1029/2008JF001087, 2009.

Christiansen, H. H., Etzelmuller, B., Isaksen, K., Juliussen, H., Farbrot, H., Humlum, O., Johansson, M., Ingeman-Nielsen, T., Kristensen, L., Hjort, J., Holmlund, P., Sannel, A. B. K., Sigsgaard, C., Akerman, H. J., Foged, N., Blikra, L. H., Pernosky, M. A., and Odegard, R. S.: The Thermal State of Permafrost in the Nordic Area during the International Polar Year 2007-2009, Permafrost and Periglacial Processes, 21, 156-181, 2010.

Davies, M. C. R., Hamza, O., and Harris, C.: The effect of rise in mean annual temperature on the stability of rock slopes containing ice-filled discontinuities, Permafrost and Periglacial Processes, 12, 137-144, 2001.

Engelhardt, M., Hauck, C., and Salzmann, N.: Influence of atmospheric forcing parameters on modelled mountain permafrost evolution, Meteorologische Zeitschrift, 19, 491-500, 10.1127/0941-2948/2010/0476, 2010.
Etzelmüller, B., Berthling, I., and Sollid, J. L.: Aspects and concepts on the geomorphologi-

\section{Temperature evolution modelling \\ of permafrost and seasonal frost}

T. Hipp et al.

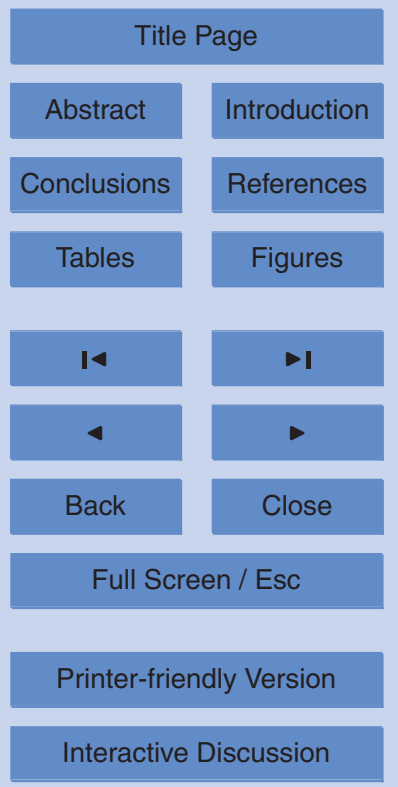


cal significance of Holocene permafrost in southern Norway, Geomorphology, 52, 87-104, 2003.

Etzelmüller, B., Farbrot, H., Gudmundsson, A., Humlum, O., Tveito, O. E., and Bjornsson, $\mathrm{H}$.: The regional distribution of mountain permafrost in Iceland, Permafrost and Periglacial Processes, 18, 185-199, 2007.

Etzelmüller, E., Schuler, T. V., Isaksen, K., Christiansen, H. H., Farbrot, H., and Benestad, R.: Modelling past and future permafrost conditions in Svalbard, The Cryosphere, 5, 1-13, doi:10.5194/tc-5-1-2011, 2011.

Farbrot, H., Etzelmüller, B., Schuler, T. V., Gudmundsson, A., Eiken, T., Humlum, O., and Bjornsson, $\mathrm{H}$.: Thermal characteristics and impact of climate change on mountain permafrost in Iceland, J. Geophys. Res.-Earth Surf., 112, F03S90 doi:10.1029/2006jf000541, 2007.

Farbrot, H., Hipp, T., Etzelmüller, E., Isaksen, K., Ødegård, R. S., Schuler, T. V., and Humlum, O.: Air and ground temperature variations observed along elevation and continentality gradients in Southern Norway, Permafrost and Periglacial Processes, submitted, 2011.

Fischer, L., Kaab, A., Huggel, C., and Noetzli, J.: Geology, glacier retreat and permafrost degradation as controlling factors of slope instabilities in a high-mountain rock wall: the Monte Rosa east face, Nat. Hazards Earth Syst. Sci., 6, 761-772, doi:10.5194/nhess-6-7612006, 2006.

20 French, H. M.: The Periglacial Environment, Addison Wesley Longman Limited, 83-85, 1996.

Gruber, S., Hoelzle, M., and Haeberli, W.: Permafrost thaw and destabilization of Alpine rock walls in the hot summer of 2003, Geophys. Res. Lett., 31, L13504, doi:10.1029/2004gl020051, 2004a.

Gruber, S., Hoelzle, M., and Haeberli, W.: Rock-wall temperatures in the Alps: modelling their topographic distribution and regional differences, Permafrost and Periglacial Processes, 15, 299-307, 2004b.

Gruber, S., and Hoelzle, M.: The thermal conductivity related cooling effect of coarse blocks, EGU General Assembly, Vienna, Austria, 2008,

Gubler, S., Fiddes, J., Gruber, S., and Keller, M.: Scale-dependent measurement and analysis of ground surface temperature variability in alpine terrain, The Cryosphere Discuss., 5, 307338, doi:10.5194/tcd-5-307-2011, 2011.

Gude, M. and Barsch, D.: Assessment of geomorphic hazards in connection with permafrost occurrence in the Zugspitze area (Bavarian Alps, Germany), Geomorphology, 66, 85-93,

\section{Temperature evolution modelling of permafrost and seasonal frost}

T. Hipp et al.

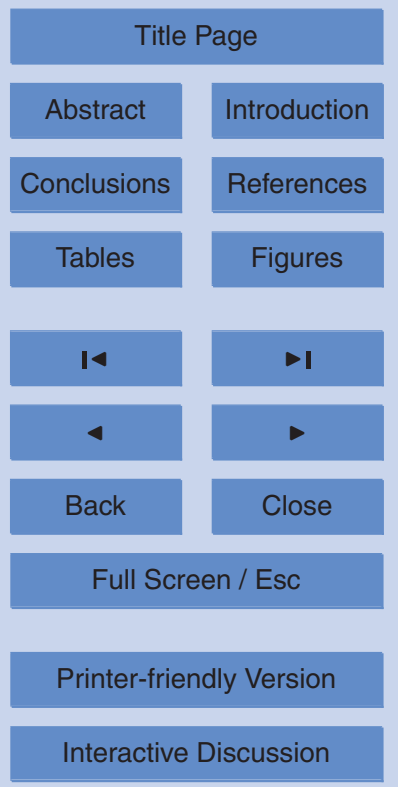


doi:10.1016/j.geomorph.2004.03.013, 2005.

Haeberli, W.: Construction, environmental problems and natural hazards in periglacial mountain belts, Permafrost and Periglacial Processes, 3, 111-124, 1992.

Hanssen-Bauer, I. and Nordli, P. Ø.: Annual and seasonal temperature variations in Norway 1876-1997 DNMI, Report, Norwegian Meteorological Institute, 1998.

Hanssen-Bauer, I.: Regional temperature and precipitaion series for Norway: Analyses of timeseries updated to 2004, Norwegian Meteorological Institute, 2005.

Harris, C., Haeberli, W., Vonder Mühll, D., and King, L.: Permafrost monitoring in the high mountains of Europe: the PACE Project in its global context, Permafrost and Periglacial

10 Processes, 12, 3-11, 2001.

Harris, C., Arenson, L. U., Christiansen, H. H., Etzelmüller, B., Frauenfelder, R., Gruber, S., Haeberli, W., Hauck, C., Hölzle, M., Humlum, O., Isaksen, K., Kääb, A., Kern-Lütschg, M. A., Lehning, M., Matsuoka, N., Murton, J. B., Nötzli, J., Phillips, M., Ross, N., Seppälä, M., Springman, S. M., and Vonder Mühll, D.: Permafrost and climate in Europe: Monitoring and modelling thermal, geomorphological and geotechnical responses, Earth-Sci. Rev., 92, 117-171, doi:10.1016/j.earscirev.2008.12.002, 2009.

Hoelzle, M., Mittaz, C., Etzelmüller, B., and Haeberli, W.: Surface Energy Fluxes and Distribution Models of Permafrost in European Mountain Areas: an Overview of Current Developments, Permafrost and Periglacial Processes, 12, 53-68, 2001.

20 Huggel, C., Salzmann, N., Allen, S., Caplan-Auerbach, J., Fischer, L., Haeberli, W., Larsen, C., Schneider, D., and Wessels, R.: Recent and future warm extreme events and high-mountain slope stability, Philos T R Soc A, 368, 2435-2459, doi:10.1098/rsta.2010.0078, 2010.

IPCC: Summary for Policymakers, in: Climate Change 2007: The Physical Science Basis. Contribution of Working Group I to the Fourth Assessment Report of the Intergovernmental Panel on Climate Change, edited by: Solomon, S., Qin, D., Manning, M., Chen, Z., Marquis, M., Averyt, K. B., Tignor, M., and. Miller, H. L., Cambridge University Press, Cambridge, UK and New York, NY, USA, 2007.

Isaksen, K., Vonder Muhll, D., Gubler, H., Kohl, T., and Sollid, J. L.: Ground surface-temperature reconstruction based on data from a deep borehole in permafrost at Janssonhaugen, Sval30 bard, Annals of Glaciology, 31, 287-294, 2000.

Isaksen, K., Holmlund, P., Sollid, J. L., and Harris, C.: Three deep alpine-permafrost boreholes in Svalbard and Scandinavia, Permafrost and Periglacial Processes, 12, 13-25, 2001.

Isaksen, K., Hauck, C., Gudevang, E., Ødegård, R. S., and Sollid, J. L.: Mountain permafrost

\section{Temperature evolution modelling of permafrost and seasonal frost}

T. Hipp et al.

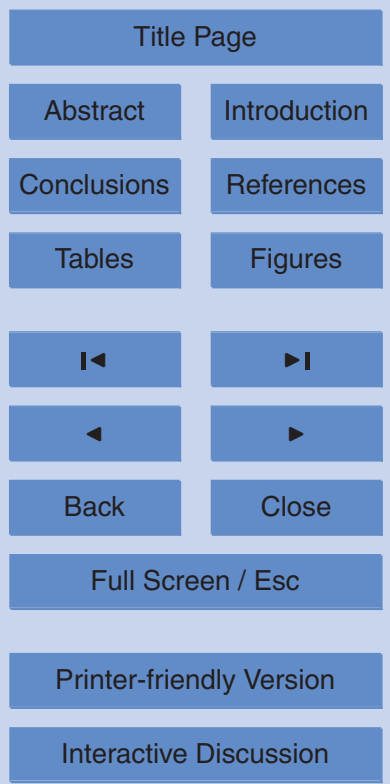


distribution on Dovrefjell and Jotunheimen, southern Norway, based on BTS and DC resistivity tomography data, Norsk Geografisk Tidsskrift - Norwegian Journal of Geography, 56, 122-136, 2002.

Isaksen, K., Heggem, E. S. F., Bakkehoi, S., Odegard, R. S., Eiken, T., Etzelmuller, B., and 5 Sollid, J. L.: Mountain permafrost and energy balance on Juvvasshoe, southern Norway, 8th International Conference on Permafrost, Zurich, Switzerland, ISI:000185049300083, 467472, 2003.

Isaksen, K., Benestad, R. E., Harris, C., and Sollid, J. L.: Recent extreme near-surface permafrost temperatures on Svalbard in relation to future climate scenarios, Geophys. Res. Lett., 34, L17502 doi:10.1029/2007gl031002, 2007.

Juliussen, $\mathrm{H}$. and Humlum, O.: Thermal regime of openwork block fields on the mountains Elgåhogna and Sølen, central-eastern Norway, Permafrost and Periglacial Processes, 19, 1-18, 2008.

Luetschg, M., Lehning, M., and Haeberli, W.: A sensitivity study of factors influencing warm/thin 15 permafrost in the Swiss Alps, J. Glaciol., 54, 696-704, doi:10.3189/002214308786570881, 2008.

Malevsky-Malevich, S. P., Molkentin, E. K., Nadyozhina, E. D., and Shklyarevich, O. B.: Numerical simulation of permafrost parameters distribution in Russia, Cold Region. Sci. Technol., 32, 1-11, 2001.

20 Mohr, M.: Comparison of Versions 1.1 and 1.0 of Gridded Temperature and Precipitation Data for Norway, Norwegian Meteorological Institute, 2009.

Noetzli, J., Gruber, S., Kohl, T., Salzmann, N., and Haeberli, W.: Three-dimensional distribution and evolution of permafrost temperatures in idealized high-mountain topography, J. Geophys. Res.-Earth Surf., 112, F02S13, doi:10.1029/2006JF000545, 2007.

Noetzli, J. and Gruber, S.: Transient thermal effects in Alpine permafrost, The Cryosphere, 3, 85-99, doi:10.5194/tc-3-85-2009, 2009.

Osterkamp, T. E., and Romanovsky, V. E.: Evidence for warming and thawing of discontinuous permafrost in Alaska, Permafrost and Periglacial Processes, 10, 17-37, 1999.

Ødegård, R. S., Liestøl, O., and Sollid, J. L.: Periglacial forms related to terrain parameters 30 in Jotunheimen, Southern Norway, 5th International Conference on Permafrost, Trondheim, Norway, 59-61, 1988.

Ødegård, R. S., Sollid, J. L., and Liestøl, O.: Ground temperature measurements in mountain permafrost, Jotunheimen, southern Norway, Permafrost and Periglacial Processes, 3, 231-

\section{$5,811-854,2011$}

\section{Temperature evolution modelling \\ of permafrost and seasonal frost}

T. Hipp et al.

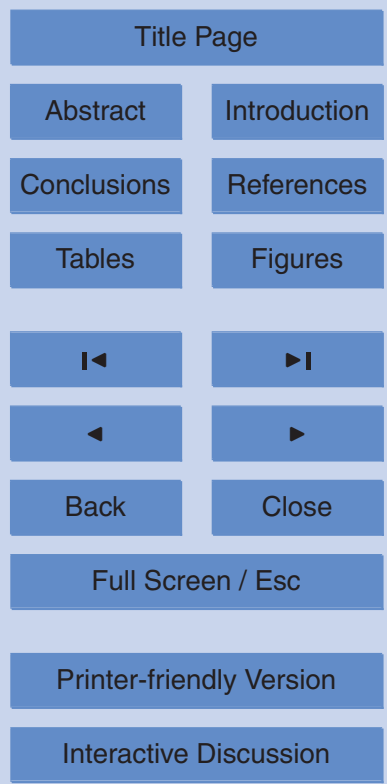

Interactive Discussion 
234, 1992.

Ødegård, R. S., Hoelzle, M., Vedel Johansen, K., and Sollid, J. L.: Permafrost mapping and prospecting in Southern Norway, Norsk Geografisk Tidsskrift - Norwegian Journal of Geography, 50, 41-53, 1996.

5 Ødegård, R. S., Isaksen, K., Mastervik, M., Billdal, L., Engler, M., and Sollid, J. L.: Comparison of BTS and Landsat TM data from Jotunheimen, southern Norway, Norsk Geografisk Tidsskrift - Norwegian Journal of Geography, 53, 226-233, 1999.

Romanovsky, V. E., Sazonova, T. S., Balobaev, V. T., Shender, N. I., and Sergueev, D. O.: Past and recent changes in air and permafrost temperatures in eastern Siberia, Global Planet.

10 Change, 56, 399-413, 2007.

Romanovsky, V. E., Drozdov, D. S., Oberman, N. G., Malkova, G. V., Kholodov, A. L., Marchenko, S. S., Moskalenko, N. G., Sergeev, D. O., Ukraintseva, N. G., Abramov, A. A., Gilichinsky, D. A., and Vasiliev, A. A.: Thermal state of permafrost in Russia, Permafrost and Periglacial Processes, 21, 136-155, 2010.

15 Sazonova, T. S., Romanovsky, V. E., Walsh, J. E., and Sergueev, D. O.: Permafrost dynamics in the 20th and 21st centuries along the East Siberian transect, J. Geophys. Res.-Atmos., 109, D01108, doi:10.1029/2003JD003680, 2004.

Serreze, M. C., Walsh, J. E., Chapin, F. S., Osterkamp, T., Dyurgerov, M., Romanovsky, V., Oechel, W. C., Morison, J., Zhang, T., and Barry, R. G.: Observational evidence of recent change in the northern high-latitude environment, Clim. Change, 46, 159-207, 2000.

Smith, S. L., Romanovsky, V. E., Lewkowicz, A. G., Burn, C. R., Allard, M., Clow, G. D., Yoshikawa, K., and Throop, J.: Thermal state of permafrost in North America: a contribution to the international polar year, Permafrost and Periglacial Processes, 21, 117-135, 2010.

Sollid, J. L., Isaksen, K., Eiken, T., and Ødegård, R. S.: The transition zone of mountain permafrost on Dovrefjell, southern Norway, Eight International Conference on Permafrost, Zurich, Switzerland, 2003,

Stendel, M. and Christensen, J. H.: Impact of global warming on permafrost conditions in a coupled GCM, Geophys. Res. Lett., 29, 1632, doi:10.1029/2001 gl014345, 2002.

30 Stocker-Mittaz, C., Hoelzle, M., and Haeberli, W.: Modelling alpine permafrost distribution based on energy-balance data: a first step, Permafrost and Periglacial Processes, 13, 271282, 2002.

Vonder Mühll, D., Noetzli, J., Roer, I., Makowski, K., and Delaloye, R.: Permafrost in Switzerland

\section{Temperature evolution modelling \\ of permafrost and seasonal frost}

T. Hipp et al.

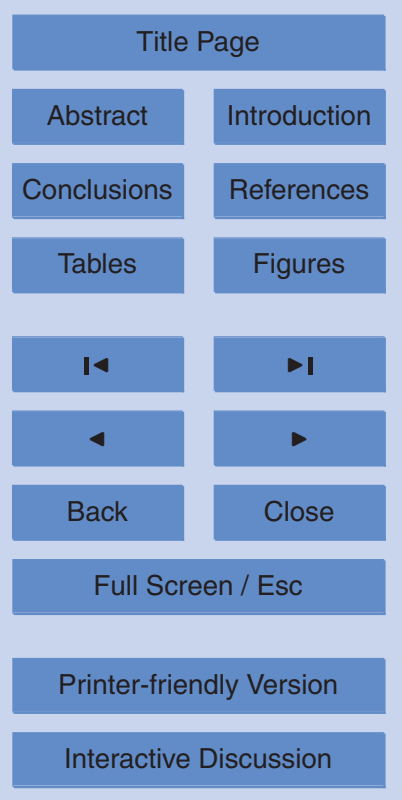


2002/2003 and 2003/2004, Glaciological Report (Permafrost) No. 4/5 of the Glaciological Commission of the Swiss Academy of Sciences (SAS) and the Department of Geography, University of Zurich, 2007.

Williams, P. J., and Smith, W.: The Frozen Earth, Cambridge University Press, 1989.

5 Zhang, Y., Chen, W. J., and Cihlar, J.: A process-based model for quantifying the impact of climate change on permafrost thermal regimes, J. Geophys. Res.-Atmos., 108, 4695, doi:10.1029/2002JD003354, 2003.

Zhang, Y., Chen, W. J., and Riseborough, D. W.: Temporal and spatial changes of permafrost in Canada since the end of the Little Ice Age, J. Geophys. Res.-Atmos., 111, D22103, doi:10.1029/2006JD007284, 2006.

Zhang, Y., Chen, W. J., and Riseborough, D. W.: Transient projections of permafrost distribution in Canada during the 21st century under scenarios of climate change, Global Planet. Change, 60, 443-456, 2008.

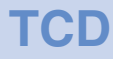

$5,811-854,2011$

\section{Temperature evolution modelling of permafrost and seasonal frost}

T. Hipp et al.

Title Page

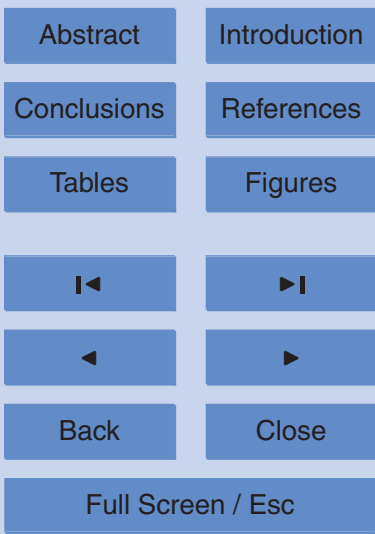

Printer-friendly Version

Interactive Discussion 
Table 1. Thermal conditions, snow cover and thawing and freezing factors implemented in the model for the two seasons 2008/2009 (S1) and 2009/2010 (S2). The maximum snow depth (SD_max) and the number of days where the snow depth exceeds $5 \mathrm{~cm}(\mathrm{SD}>5 \mathrm{~cm})$ give an indication of the local snow cover.

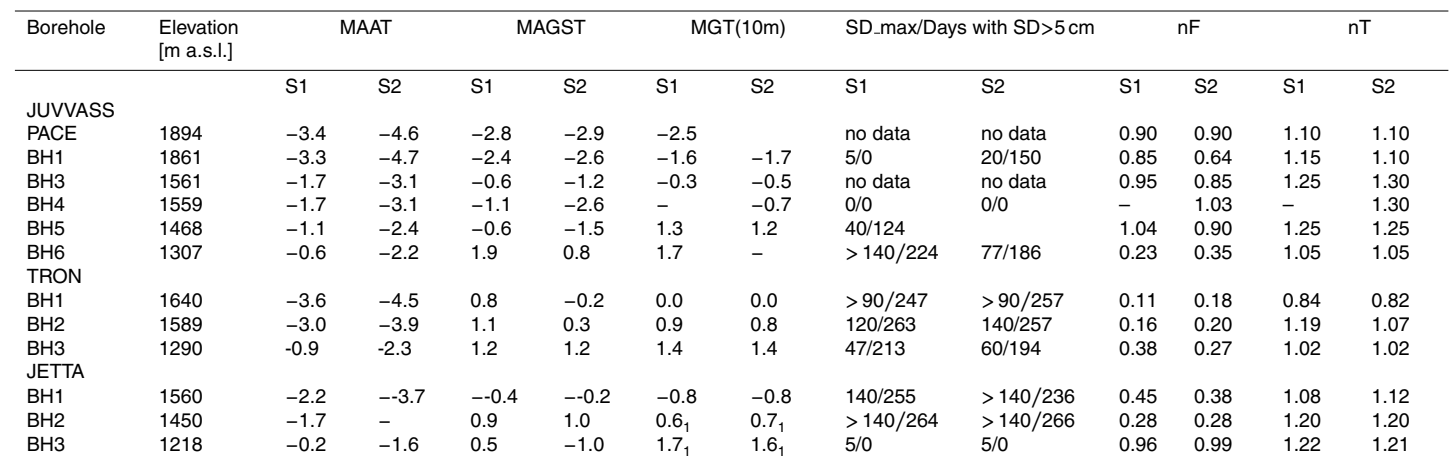

${ }^{1} 9.5 \mathrm{~m}$ depth.

\section{Temperature evolution modelling of permafrost and seasonal frost}

T. Hipp et al.

\section{Title Page}

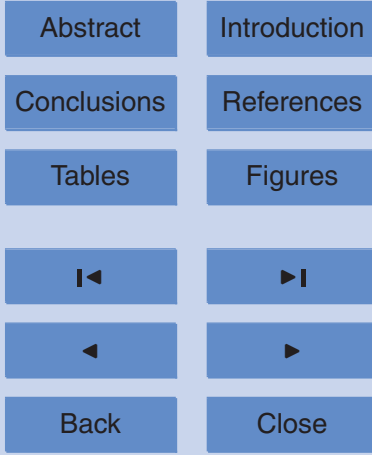

Full Screen / Esc

Printer-friendly Version

Interactive Discussion 
Table 2. Ground properties for different substrates, surface cover and bedrock used in this study. Here, $k$ is thermal conductivity, $c$ is specific heat capacity, VWC is the volumetric water content and $\rho$ is the density.

\begin{tabular}{lllll}
\hline & $k\left[\mathrm{~W} \mathrm{~K}^{-1} \mathrm{~m}^{-1}\right]$ & $\mathrm{c}\left[\mathrm{J} \mathrm{kg}^{-1} \mathrm{~K}^{-1}\right]$ & $\mathrm{VWC}[\%]$ & $\rho\left[\mathrm{kg} \mathrm{m}^{-3}\right]$ \\
\hline Block field & $0.8-1.4$ & 800 & $5-20$ & $1200-1600$ \\
Vegetated surface layer & 0.8 & 800 & $14-15$ & $1000-1300$ \\
Coarse grained material & $1.8-2.3$ & 800 & 4 & $1400-2000$ \\
Fine moraine material & $1.0-1.8$ & 800 & $4-8$ & $1500-1800$ \\
Bedrock & $2.3-3.0$ & $800-900$ & $0.5-2$ & $2000-2800$ \\
\hline
\end{tabular}

Temperature evolution modelling of permafrost and seasonal frost

T. Hipp et al.

Title Page

Abstract Introduction

Conclusions

References

Tables

Figures

14

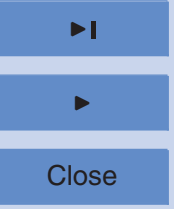

Back

Full Screen / Esc

Printer-friendly Version

Interactive Discussion 
Table 3. Modeled and measured ground surface temperature (GST), ground temperature (GT) and active layer thickness (ALT). The root mean square error (RMSE) was chosen to estimate the error of the modeled results.

\begin{tabular}{|c|c|c|c|c|c|c|c|c|}
\hline & \multicolumn{2}{|c|}{ GST } & \multicolumn{2}{|c|}{ GT } & \multicolumn{2}{|c|}{ Measured ALT [m] } & \multicolumn{2}{|c|}{ Modeled ALT [m] } \\
\hline & $r^{2}$ & $\begin{array}{l}\text { RMSE } \\
\left({ }^{\circ} \mathrm{C}\right)\end{array}$ & $r^{2}$ & $\begin{array}{l}\text { RMSE } \\
\left({ }^{\circ} \mathrm{C}\right)\end{array}$ & $2008 / 2009$ & $2009 / 2010$ & $2008 / 2009$ & $2009 / 2010$ \\
\hline \multicolumn{9}{|c|}{ JUVVASS } \\
\hline PACE & 0.85 & 2.7 & 0.98 & 0.5 & 2.2 & 2.3 & 2.1 & 2.1 \\
\hline $\mathrm{BH} 1$ & 0.84 & 2.3 & 0.97 & 0.5 & 1.4 & 1.5 & 1.4 & 1.3 \\
\hline $\mathrm{BH} 3$ & 0.87 & 2.7 & 0.98 & 0.6 & 8.5 & 6.8 & 8.2 & 6.4 \\
\hline $\mathrm{BH} 4$ & 0.93 & 2.1 & 0.99 & 0.4 & - & 8.6 & - & 8.3 \\
\hline $\mathrm{BH} 5$ & 0.88 & 2.7 & 0.99 & 0.5 & - & - & - & - \\
\hline $\mathrm{BH} 6$ & 0.91 & & 0.85 & 0.7 & - & - & - & - \\
\hline \multicolumn{9}{|l|}{ TRON } \\
\hline $\mathrm{BH} 1$ & 0.77 & 1.3 & 0.99 & 0.1 & 10.7 & 11.1 & 11.7 & 10.7 \\
\hline $\mathrm{BH} 2$ & 0.91 & & 0.96 & 0.4 & - & - & - & - \\
\hline $\mathrm{BH} 3$ & 0.93 & 1.2 & 0.97 & 0.4 & - & - & - & - \\
\hline \multicolumn{9}{|c|}{ JETTA } \\
\hline $\mathrm{BH} 1$ & 0.84 & 1.9 & 0.99 & 0.3 & 8.0 & 7.32 & 8.1 & 7.9 \\
\hline $\mathrm{BH} 2$ & 0.81 & 2.1 & 0.99 & 0.3 & - & - & - & - \\
\hline $\mathrm{BH} 3$ & 0.96 & 1.6 & 0.99 & 0.9 & - & - & - & - \\
\hline
\end{tabular}

\section{Temperature evolution modelling of permafrost and seasonal frost}

T. Hipp et al.

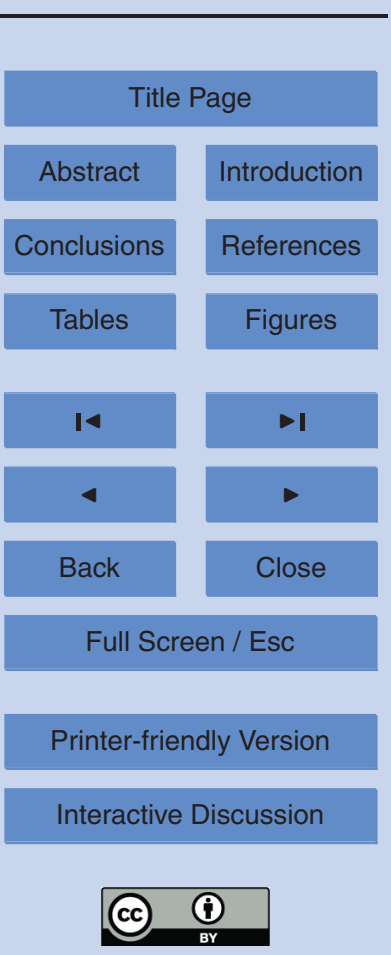


Table 4. Surface air temperature change at each borehole from the $1860 \mathrm{~s}$ until the $2090 \mathrm{~s}$. MAT = mean air temperature, ALRT = altitudinal lapse rate.

\begin{tabular}{llllll}
\hline & $\begin{array}{l}\text { Elevation } \\
{[\mathrm{m} \text { a.s.I. }]}\end{array}$ & $\begin{array}{l}\mathrm{MAT}(1865 / 1875) \\
{\left[{ }^{\circ} \mathrm{C}\right]}\end{array}$ & $\begin{array}{l}\mathrm{MAT}(2008 / 2009) \\
{\left[{ }^{\circ} \mathrm{C}\right]}\end{array}$ & $\begin{array}{l}\Delta \mathrm{T} \\
{\left[{ }^{\circ} \mathrm{C}\right]}\end{array}$ & $\begin{array}{l}\text { ALRT } \\
{\left[{ }^{\circ} \mathrm{C} / 100 \mathrm{~m}\right]}\end{array}$ \\
\hline JUVVASS & & & & & \\
PACE & 1894 & -4.8 & -3.4 & 1.4 & \\
BH1 & 1861 & -4.8 & -3.3 & - & \\
BH2 & 1771 & -4.3 & - & 1.6 & \\
BH3 & 1561 & -3.3 & -1.7 & 1.6 & \\
BH4 & 1559 & -3.3 & -1.7 & 1.7 & \\
BH5 & 1468 & -2.8 & -1.1 & 1.4 & \\
BH6 & 1314 & -2.0 & -0.6 & 1.9 & \\
TRON & & & & 2.2 & \\
BH1 & 1640 & -5.5 & -3.6 & 1.8 & \\
BH2 & 1589 & -5.1 & -3.0 & & \\
BH3 & 1290 & -2.7 & -0.9 & & \\
JETTA & & & & & \\
BH1 & 1560 & -4.1 & -2.2 & & \\
BH2 & 1450 & -3.6 & -1.7 & & \\
BH3 & 1218 & -2.1 & -0.2 & & \\
\hline
\end{tabular}

5, 811-854, 2011

Temperature evolution modelling of permafrost and seasonal frost

T. Hipp et al.

\section{Title Page}

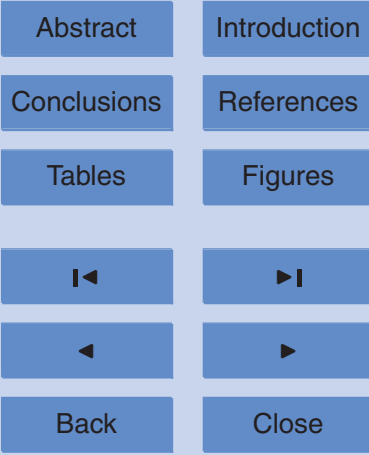

Full Screen / Esc

Printer-friendly Version

Interactive Discussion 
$5,811-854,2011$

\section{Temperature evolution modelling of permafrost and seasonal frost}

T. Hipp et al.

Table 5. Changes in MAGST and increase in RMSE introduced by the use of $n$-factors.

\begin{tabular}{|c|c|c|c|c|c|c|c|c|}
\hline & \multicolumn{4}{|c|}{ JUVVASS } & \multicolumn{3}{|c|}{ TRON } & JETTA \\
\hline & $\mathrm{BH} 1$ & $\mathrm{BH} 3$ & $\mathrm{BH} 5$ & $\mathrm{BH} 6$ & $\mathrm{BH} 1$ & $\mathrm{BH} 2$ & $\mathrm{BH} 3$ & $\mathrm{BH} 1$ \\
\hline$\triangle M A G S T$ & 1.1 & 0.53 & 0.58 & 0.51 & 0.42 & 0.38 & 0.45 & 0.66 \\
\hline$\Delta \mathrm{RMSE}$ & 0.72 & 0.15 & 0.13 & 0.13 & 0.09 & 0.10 & 0.23 & 0.23 \\
\hline
\end{tabular}

Title Page

Abstract

Introduction

Conclusions

References

Tables

Figures

14

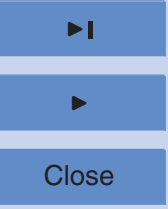

Back

Full Screen / Esc

Printer-friendly Version

Interactive Discussion 

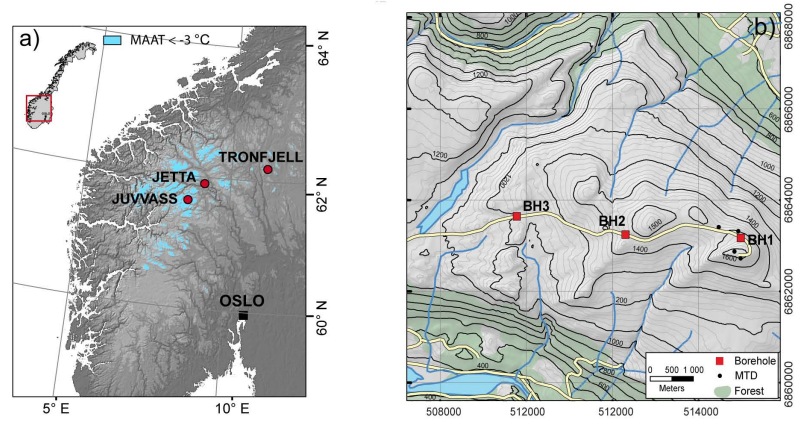

\section{TCD}

$5,811-854,2011$

\section{Temperature evolution modelling of permafrost and seasonal frost}

T. Hipp et al.
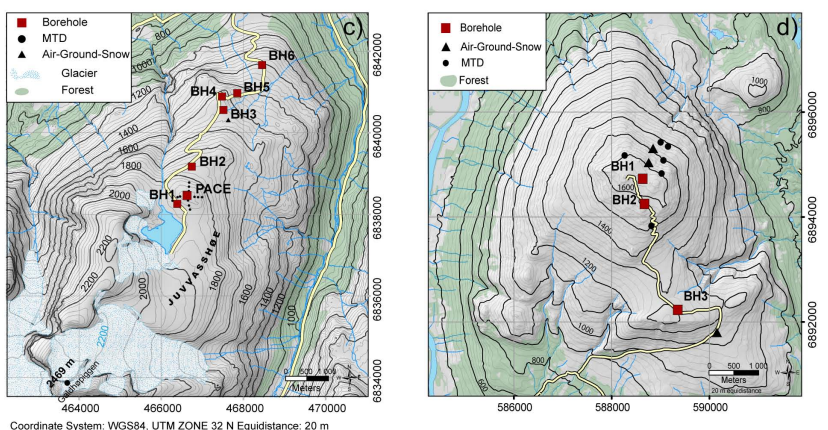

Title Page

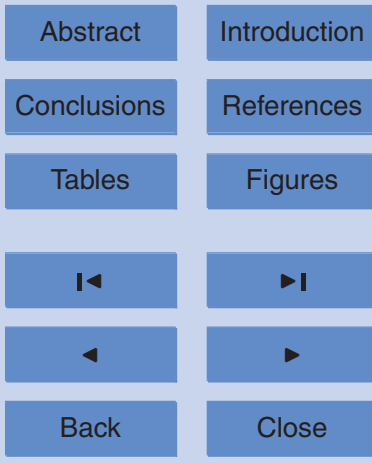

Fig. 1. Location of the study sites and boreholes in Norway (a). As a rough estimate of possible permafrost distribution all areas with MAAT $<-3^{\circ} \mathrm{C}$ are shown. Local site overview of (b) Jetta, (c) Juvvass and (d) Tron.

\section{Full Screen / Esc}

Printer-friendly Version

Interactive Discussion 


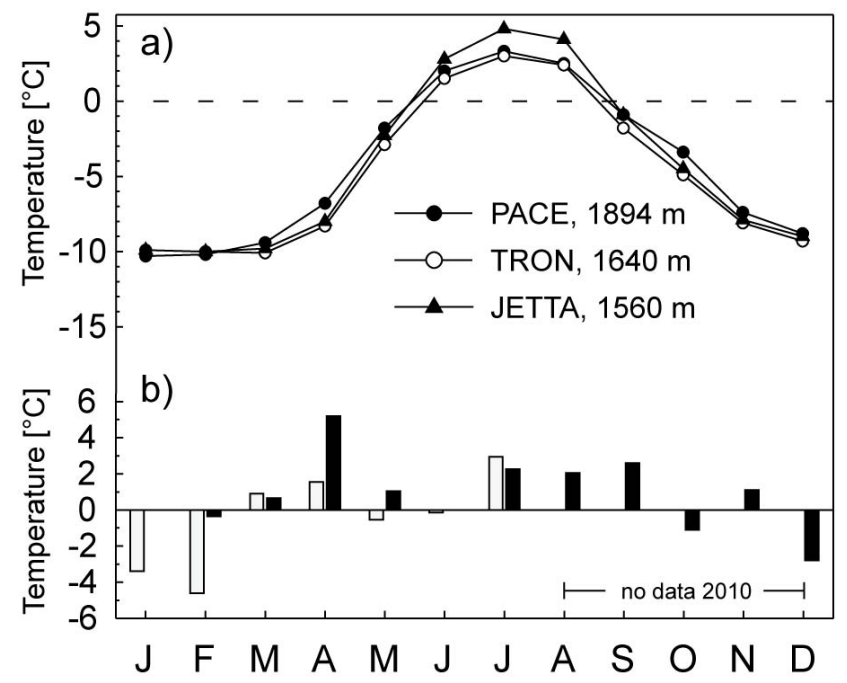

\section{Temperature evolution modelling of permafrost and seasonal frost}

T. Hipp et al.

Title Page

Abstract

Conclusions

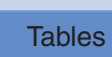

References

Tables

Figures

14

4

Back

Full Screen / Esc

Printer-friendly Version

Interactive Discussion 

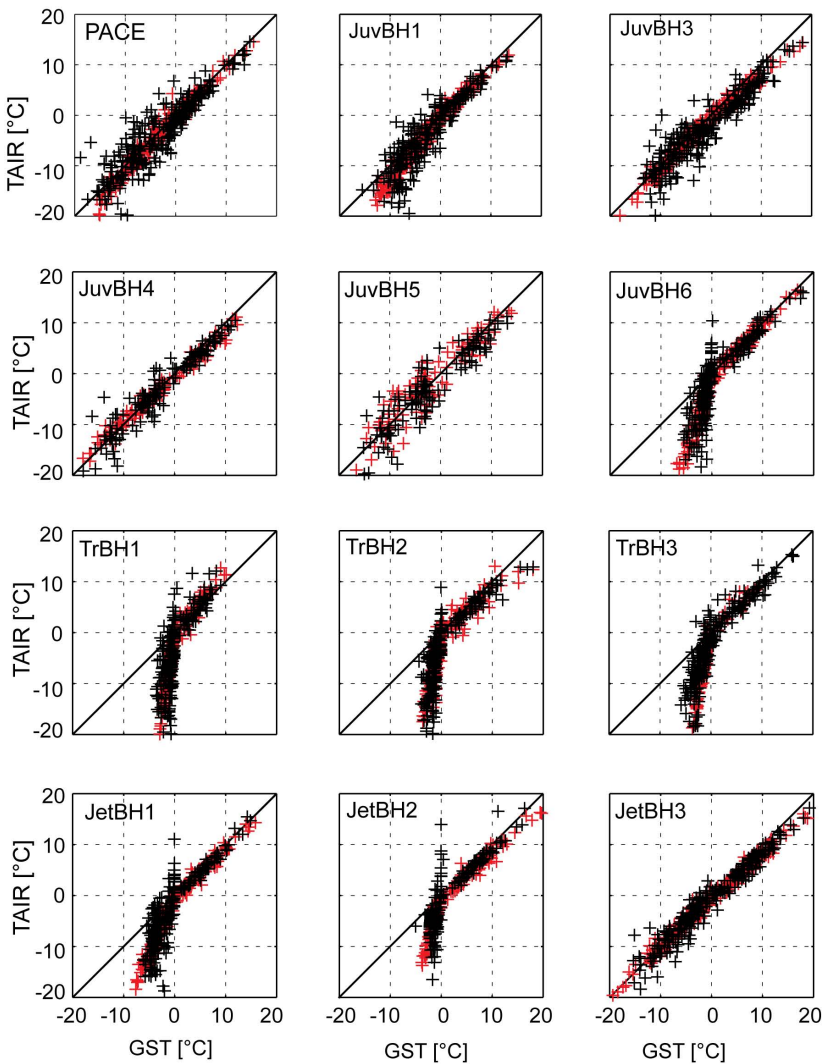

Fig. 3. Correlation of measured (black) and modelled (red) GST to $T_{\mathrm{AIR}}$ at all borehole sites. High linear correlations can be found at sites having only thin and not persistent snow cover, being PACE $\left(r^{2}=0.82\right)$, Juv-BH1 $\left(r^{2}=0.80\right)$, Juv-BH3 $\left(r^{2}=0.84\right)$, Juv-BH4 $\left(r^{2}=0.92\right)$, Juv$\mathrm{BH} 5\left(r^{2}=0.87\right)$, and Jet-BH3 $\left(r^{2}=0.95\right)$. The model reproduced the GST with good accuracy even at sites that show the effect of a long and thick snow cover (e.g. Tron, Jet-BH1, Jet-BH2).

TCD

$5,811-854,2011$

\section{Temperature evolution modelling of permafrost and seasonal frost}

T. Hipp et al.

\section{Title Page}

\section{Abstract}

Conclusions

\section{Tables}

14

14

$\triangleleft$

Back

Full Screen / Esc

Printer-friendly Version

Interactive Discussion 

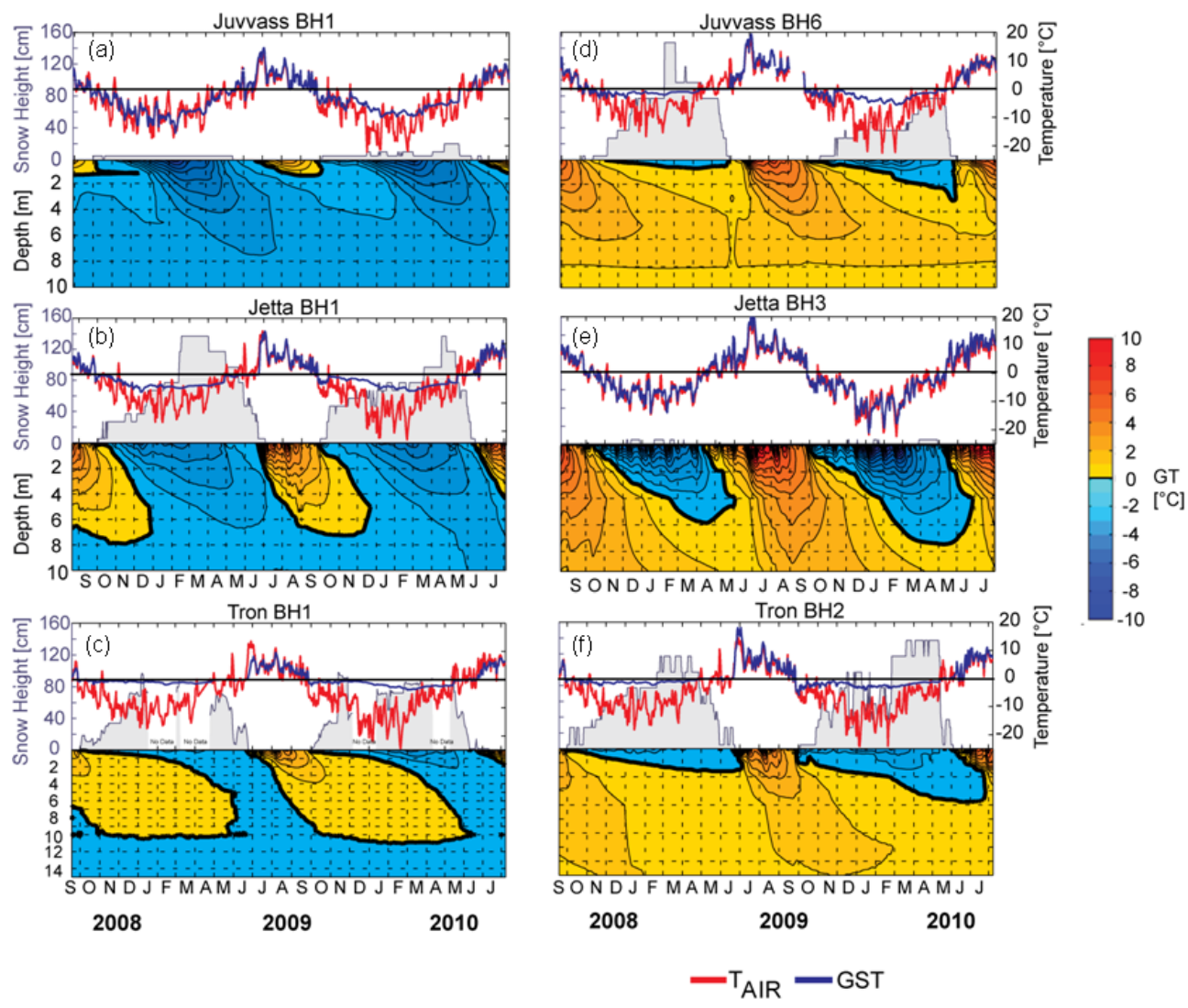

Fig. 4. Thermal regime of permafrost (a, b, $\mathbf{c})$ and non-permafrost (d, e, f) boreholes including GT, GST, $T_{\text {AIR }}$ and snow cover.

\section{TCD}

5, 811-854, 2011

\section{Temperature evolution modelling of permafrost and seasonal frost}

T. Hipp et al.

\section{Title Page}

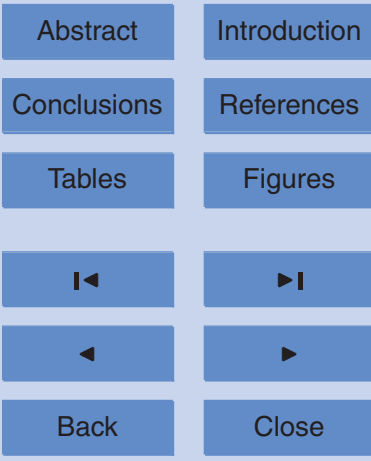

Full Screen / Esc

Printer-friendly Version

Interactive Discussion 


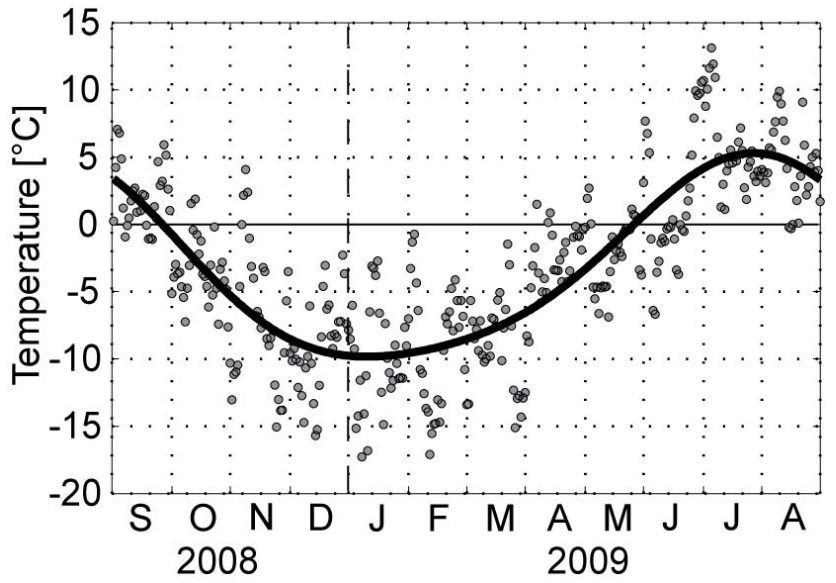

Fig. 5. Measured daily air temperature (points) from September 2008-August 2009 at Juv-BH1 are fitted with a 2nd degree Fourier series (solid line) used to simulate a typical seasonal cycle.

\section{Temperature evolution modelling of permafrost and seasonal frost}

T. Hipp et al.

\section{Title Page}

\section{Abstract}

Introduction

Conclusions

References

Tables

Figures

14

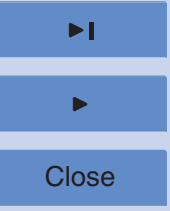

Back

Full Screen / Esc

Printer-friendly Version

Interactive Discussion 

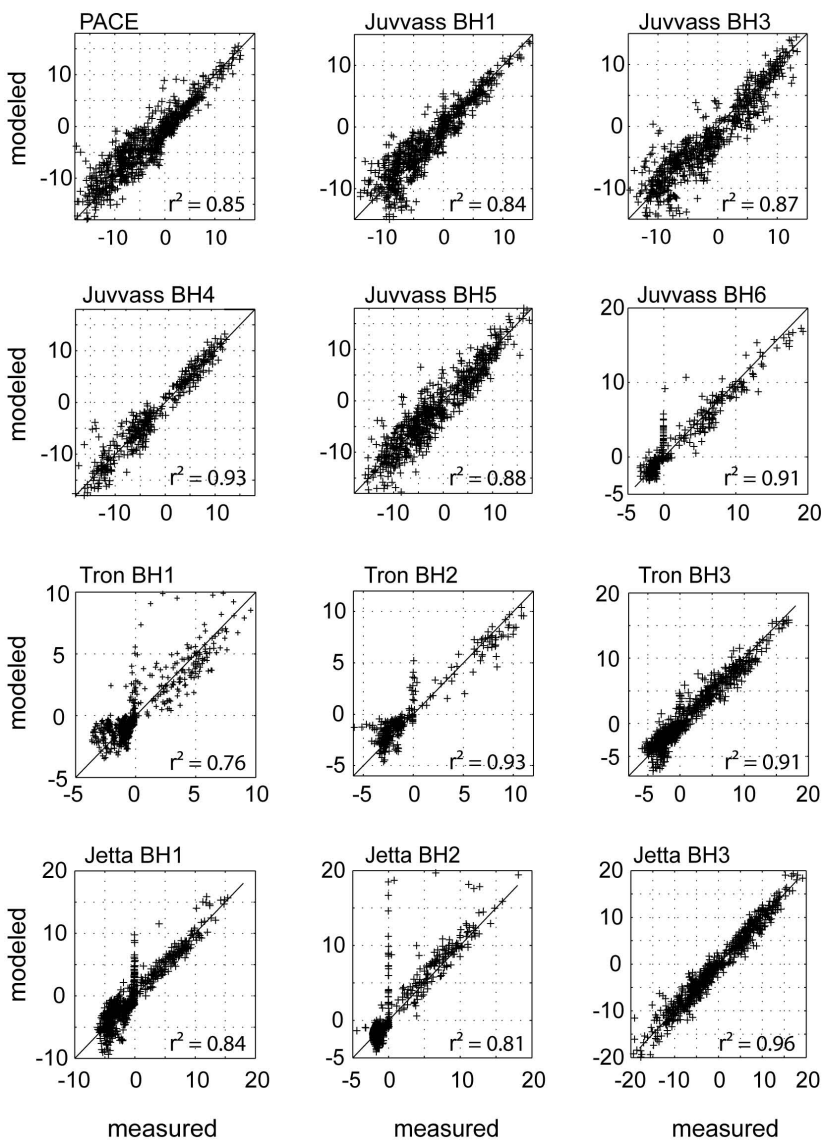

Fig. 6. Correlation between modelled and measured GST at all borehole sites. GST was simply modelled using $n$-factors. Good correlations are found at all sites with $r^{2}>0.80$. Very good model results are achieved at bedrock sites without or very restricted snow cover (Juv$\mathrm{BH} 4$, Jet-BH3) with $r^{2}>0.90$.

\section{Temperature evolution modelling of permafrost and seasonal frost}

T. Hipp et al.

Title Page

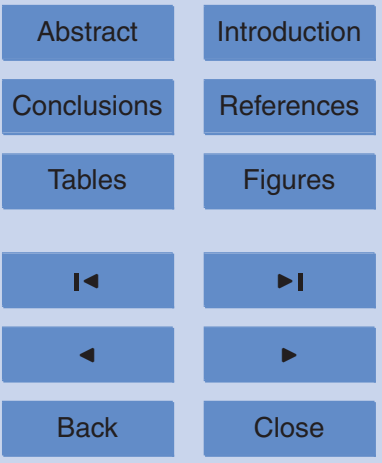

Full Screen / Esc

Printer-friendly Version

Interactive Discussion 

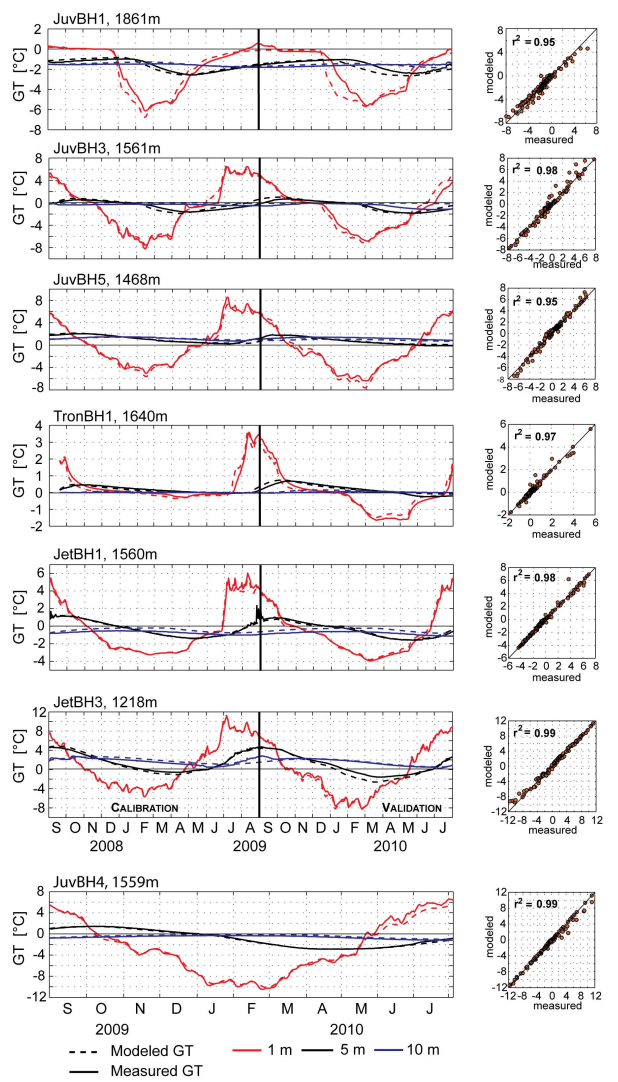

Fig. 7. (Left panels) Measured (solid lines) and modelled (dashed lines) ground temperatures (GT) at $1 \mathrm{~m}$ (red), $5 \mathrm{~m}$ (black) and $10 \mathrm{~m}$ (blue) depth during the calibration (2008/2009) and the validation period (2009/2010). Only one season was available for calibration and validation for Juv-BH4. (Right panels) Scatter plots of measured against modelled GT with linear correlation coefficient.

\section{Temperature evolution modelling of permafrost and seasonal frost}

T. Hipp et al.

Title Page

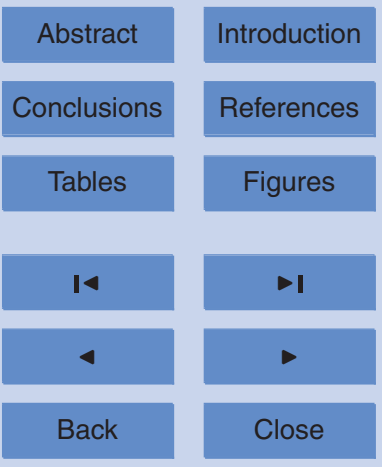

Full Screen / Esc

Printer-friendly Version

Interactive Discussion 


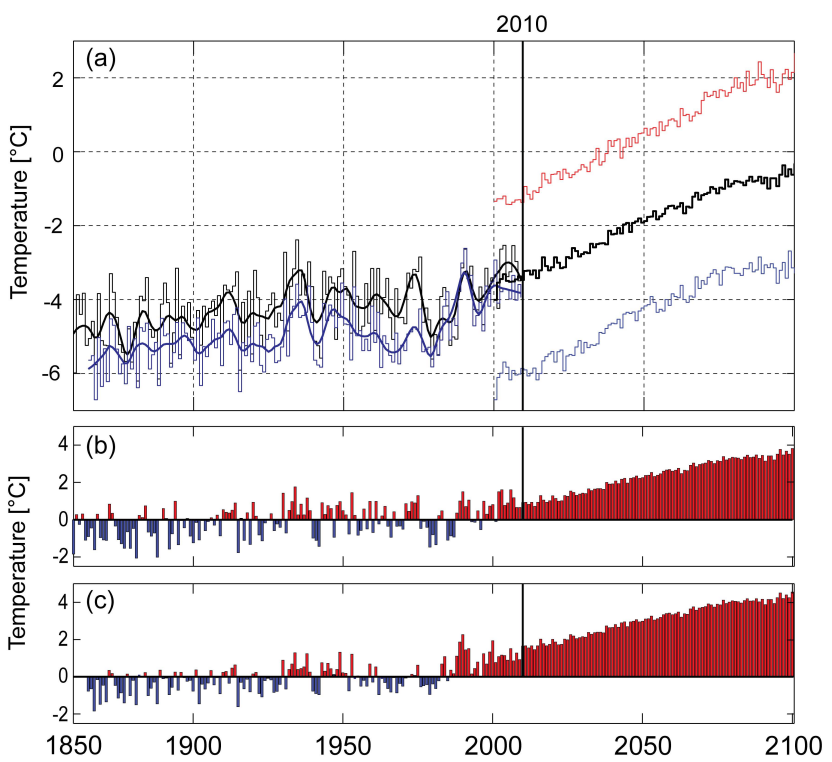

\section{Temperature evolution modelling of permafrost and seasonal frost}

T. Hipp et al.

Title Page

Abstract Introduction

Conclusions References

Tables Figures

14 - I

Fig. 8. (a) Historic air temperature series at the uppermost borehole at Juvvass (black) and Tronfjell (blue). The bold line represents the 7-year Gaussian-filtered series with a three $\mathrm{K}$ standard deviation. From 2010 the median (bold black), 90 percentile (red) and 10 percentile (blue) of the downscaled A1B climate change scenario at Juv-BH1 is shown. The lower panels show the deviation of MAAT to the 1961-1990 climate normal at Juvvass (b) and Tron (c). 


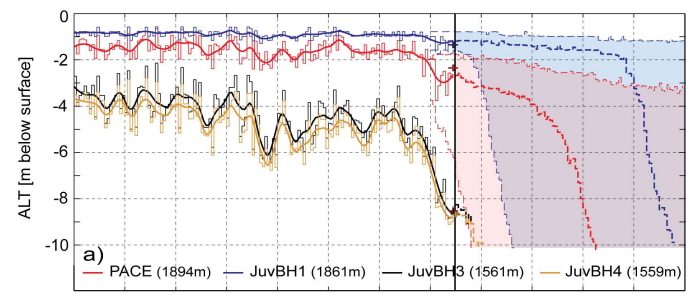

$5,811-854,2011$
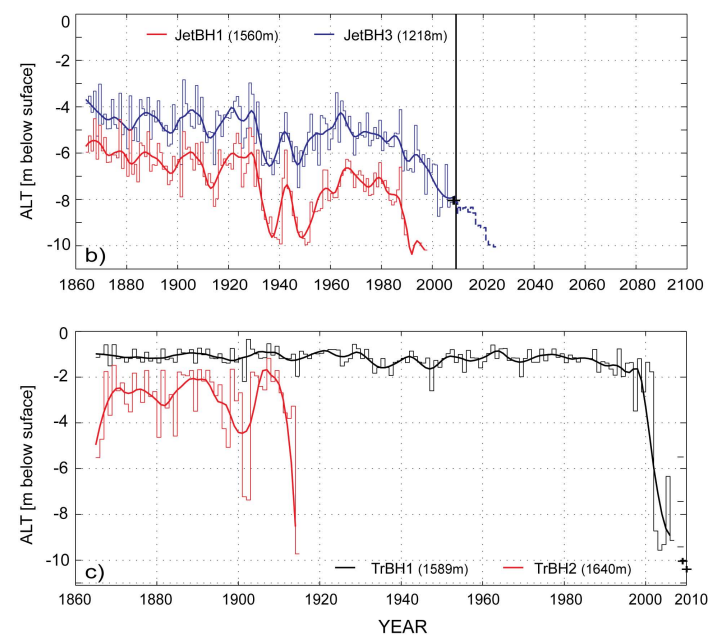

\section{Temperature evolution modelling of permafrost and seasonal frost}

T. Hipp et al.

Fig. 9. Past and future active layer thickness (ALT) from 1860 to 2100 at Juvvasshøe (a), Jetta (b) and Tron (c). Future ALT was modelled with the median of the downscaled scenario temperatures (bold dashed lines) and in the case of Juv-BH1 and PACE additionally using the the 90 and 10 percentile (shading) (a). The bold lines represents a 7-year Gaussian-filtered series, measured ALT are marked by crosses.

Title Page

\section{Abstract}

Introduction

Conclusions

References

Tables

Figures

14

4

Back

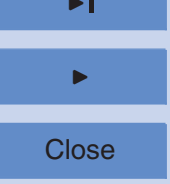

Full Screen / Esc

Printer-friendly Version

Interactive Discussion 


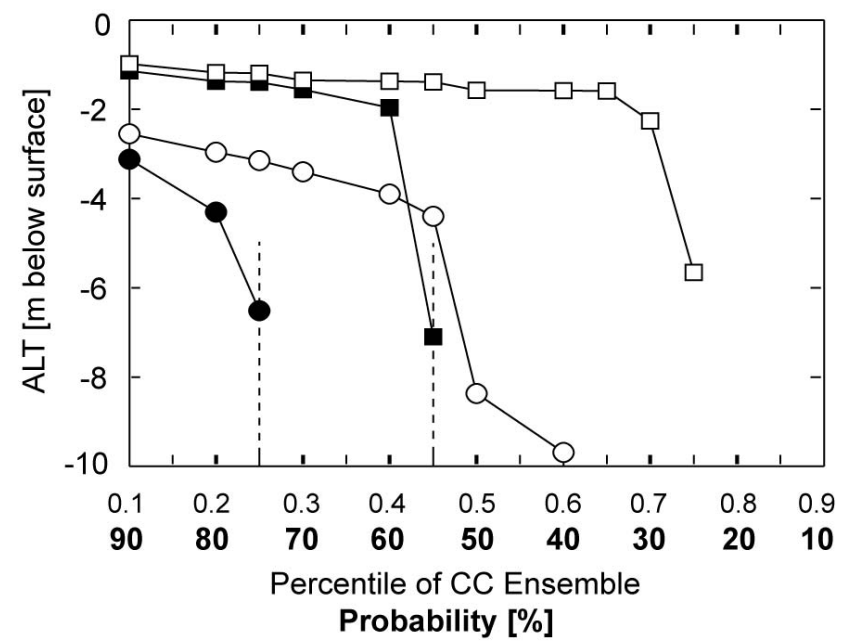

\section{Temperature evolution modelling of permafrost and seasonal frost}

T. Hipp et al.

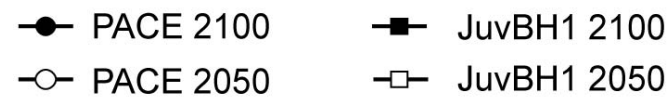

Fig. 10. Probability of complete permafrost thaw at the years 2050 (black) and 2100 (white) at Juv-BH1 (squares) and PACE (circles). The model was driven with all percentiles (every 5th percentile) analyzing the percentile where permafrost at the according year disappeared in the model results.

Title Page

\section{Abstract}

Introduction

Conclusions

References

Tables

Figures

14

$\rightarrow$

$\triangleleft$

Back

Close

Full Screen / Esc

Printer-friendly Version

Interactive Discussion 